\title{
Coal Resources of
}

\section{Western Pennsylvania}

$\begin{array}{llllllllllllllllll}\text { G E L O G I C A L } & \text { S U R V E Y B U L L T I N } & 1143\end{array}$

This volume was published

as separate chapters $A-C$

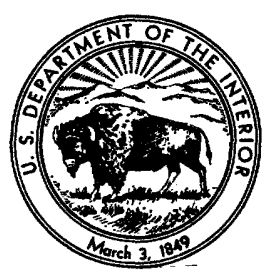


UNITED STATES DEPARTMENT OF THE INTERIOR

ROGERS G. B. MORTON, Secretary

\section{GEOLOGICAL SURVEY}

W. A. Radlinski, Acting Director 


\section{CONTENTS}

[Letters designate the separately published chapters]

(A) Coal resources of Beaver County, Pennsylvania, by Elmer D. Patterson.

(B) Coal resources of Lawrence County, Pennsylvania, by J. A. Van Lieu and Elmer D. Patterson.

(C) Coal resources of Butler County, Pennsylvania, by Elmer D. Patterson and J. A. Van Lieu. 

Coal Resources of

Beaver County

Pennsylvania

By ELMER D. PATTERSON

COAL RESOURCES OF WESTERN PENNSYLVANIA

G E O L O G I A L S U R V EY B U L L E T I N $1143-$ A

Prepared in cooperation with the Pennsylvania Bureau of Topographic and Geologic Survey

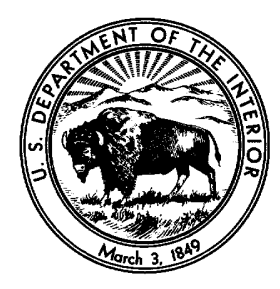




\title{
UNITED STATES DEPARTMENT OF THE INTERIOR
}

\author{
STEWART L. UDALL, Secretary
}

\author{
GEOLOGIGAL SURVEY
}

Thomas B. Nolan, Director 


\section{CONTENTS}

\begin{tabular}{|c|c|}
\hline & Page \\
\hline Abstract_. & A1 \\
\hline Introduction & \\
\hline Acknowledgments & 4 \\
\hline Stratigraphy & 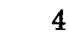 \\
\hline Pottsville Formation & 5 \\
\hline Allegheny Formation & 7 \\
\hline Conemaugh Formation & 10 \\
\hline Monongahela Formation & 13 \\
\hline Structure & 14 \\
\hline Coal reserves. & 14 \\
\hline Summary of reserves. & 15 \\
\hline Lower Kittanning coal bed & 15 \\
\hline Middle Kittanning coal bed.-..- & 15 \\
\hline Upper Kittanning coal bed . . . . . & 17 \\
\hline Lower Freeport coal bed & 17 \\
\hline oal bed.... & 17 \\
\hline d & 17 \\
\hline k coal bed & 17 \\
\hline bed & 18 \\
\hline n preparing estimates of reserves & 18 \\
\hline cording to characteristics of the coal & 18 \\
\hline o measured, indicated, and inferred reserves.... & 20 \\
\hline iginal, remaining, and recoverable reserves.. & 20 \\
\hline aking calculations & 21 \\
\hline ates of the coal reserves in Beaver County & 27 \\
\hline Rank and quality of coal & 27 \\
\hline Coal production...- & 32 \\
\hline References cited_ & 32 \\
\hline
\end{tabular}

\section{ILLUSTRATIONS}

[Plates are in pocket]

Plate 1. Generalized section of Pennsylvanian rocks.

2. Geologic map of Beaver County.

3. Measured stratigraphic sections from Smiths Ferry to Chewton.

4. Measured stratigraphic sections from Ambridge to Wurtemburg.

5. Maps of principal coal beds in Beaver County.

Figure 1. Map showing location of Beaver County 


\section{TABLES}

TABLE 1. Summary of estimated original coal reserves, in millions of short tons, in Beaver County by quadrangle and by bed...--

2. Classification of coals by rank

3. Estimated original bituminous coal reserves, in millions of short tons, in Beaver County under less than 60 feet of overburden

4. Estimated original bituminous coal reserves, in millions of short tons, in Beaver County under 60-1,000 feet of overburden

5. Analyses of coal samples from Beaver County and adjacent areas. 


\title{
COAL RESOURCES OF WESTERN PENNSYLVANIA
}

\section{COAL RESOURGES OF BEAVER GOUNTY, PENNSYLVANIA}

\author{
By Elmer D. Patterson
}

\begin{abstract}
Rocks of Pennsylvanian age in Beaver County, on the western border of Pennsylvania, are divided, in ascending order, into the Pottsville, Allegheny, Conemaugh, and Monongahela Formations. These formations have a total thickness of about 1,000 feet in the county and consist of interbedded sandstone, siltstone, shale. limestone, and 21 coal beds. Except for a few very minor, broad folds, the strata dip gently to the southwest so that the oldest rocks are exposed in the deepest valleys in northern Beaver County, and the youngest Pennsylvanian rocks cap the hills in the southern part.

Most of the coal reserves in Beaver County are bituminous coal in the Lower Kittanning, Middle Kittanning, Lower Freeport, and Upper Freeport coal beds of the Allegheny Formation. These have been the most extensively mined coal beds in the county, but they still constitute about 98 percent of the total remaining reserves. Two percent of the remaining reserves is in the Mahoning and Brush Creek coal beds of the Conemaugh Formation and in the Pittsburgh coal bed of the Monongahela Formation, which has been largely mined out.

Total original reserves of high-volatile bituminous coal in beds thicker than 14 inches are estimated to be 2,517 million short tons, of which 2,489 million tons are remaining reserves.
\end{abstract}

\section{INTRODUCTION}

Beaver County, Pa., is a part of one of the major coal fields in the United States, the Northern Applachian coal field, and the bituminous coal produced in this county has contributed materially to the great industrialization of western Pennsylvania. The large reserves of coal remaining in the county are a major natural resource, and the purpose of this report, which was prepared in cooperation with the Pennsylvania Bureau of Topographic and Geologic Survey, is to establish reliable estimates of these reserves to aid in future planning and development of this area.

Beaver County, with an area of 441 square miles (fig. 1), is in the extreme western part of Pennsylvania between lat $40^{\circ} 29^{\prime}$ and $40^{\circ} 51^{\prime}$ N. and long $80^{\circ} 09^{\prime}$ and $80^{\circ} 31^{\prime} \mathrm{W}$. 


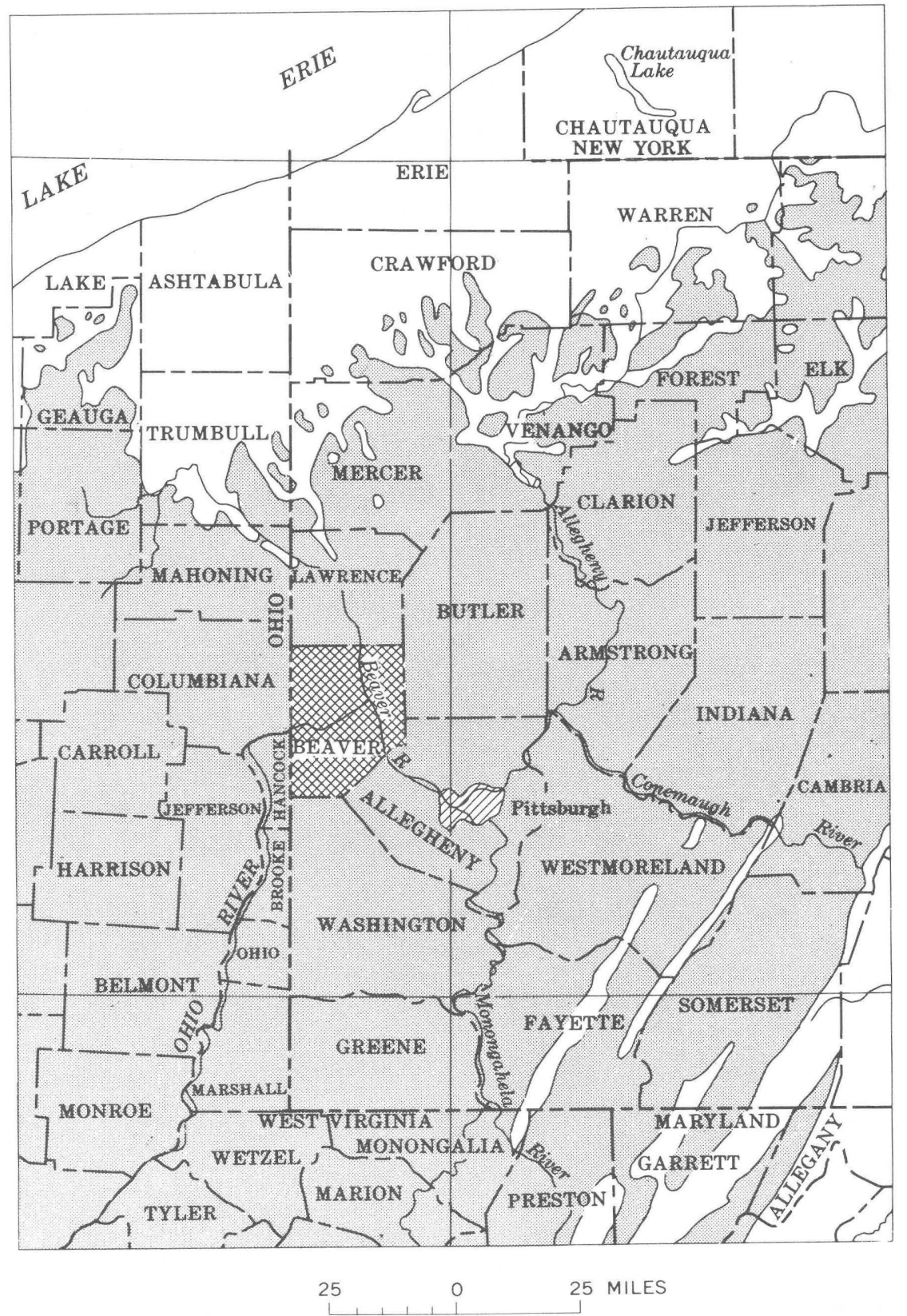

Figure 1.-Map showing location of Beaver County, Pa. (cross hatched), in the northern Appalachian coal field. 
The southeast border of the county is 17 miles northwest of Pittsburgh, and the west boundary forms part of Pennsylvania's boundary with Ohio and West Virginia. The largest towns in the county are Aliquippa, Beaver Falls, Ambridge, and New Brighton; Beaver is the county seat. These towns are located along the navigable Ohio and Beaver Rivers.

Beaver County lies in the northern part of the Allegheny Plateau, where the plateau is moderately dissected by rivers and streams that have cut deep narrow valleys. The highest point in the county is Big Knob (altitude 1,383 feet), which is located in the east-central part of the county between Unionville and Knob, and the lowest point is where the Ohio River crosses the west boundary of the county at an altitude of about 655 feet. The general altitude of the plateau is about 1,100 feet, but local relief of $300-500$ feet is common in many parts of the county, particularly near the major streams.

The principal drainage feature of Beaver County is the confluence of the Beaver and Ohio Rivers, near the center of the county. The Ohio River, which flows northwestward from Pittsburgh, enters the county from the southeast but changes its course near the center of the county to flow west-southwest out of Beaver County and Pennsylvania into Ohio. The Beaver River enters the county near the middle of the north boundary and flows almost due south to join the Ohio. River at Rochester. The many smaller streams that flow into these two rivers form a dendritic drainage pattern throughout the county.

The stratigraphy and structure of Beaver County have been described in several older reconnaissance and detailed geologic reports. A reconnaissance report on the geology of Beaver County by I. C. White was published in 1878. Subsequent detailed geologic reports on quadrangles in the county are those by Woolsey (1906), Munn (1911), DeWolf (1929), and Richardson (1936). The coal reserves were estimated by Reese and Sisler (1928), and a study of the ground water was made by Van Tuyl and Klein (1951).

This report is a re-evaluation of the coal resources of Beaver County based on standard methods adopted by the U. S. Geologicical Survey in estimating coal reserves. In preparing these estimates, all available geologic maps, reports, mine maps and records, aerial photographs, and drill-hole records were studied, and additional field studies were made. The geologic map (pl. 2) of the county, which shows the distribution of the major coal beds, was compiled largely from published geologic maps. Much of the northeastern part of the county was remapped, and for other parts of the county many outcrop lines of coal beds shown on older maps were adjusted to conform to the topography shown on the modern $71 / 2$-minute quadrangle maps. This investigation began in the fall of 1955 and was completed in 1956. 


\section{ACKNOWLEDGMENTS}

The cooperation of many individuals and organizations associated with the coal mining industry in Beaver County is acknowledged. Especially helpful were Daniel Baker, County Surveyor; the McLain Fire Brick Co.; the Sunnyside Coal Co.; the Courtney Coal Co.; the Craig Brothers Coal Co.; the Oscar Newton Coal Co.; the Tasa Coal Co.; and the Dow Lin Coal Colliery. The Topographic and Geologic survey of Pennsylvania, the Pennsylvania Department of Health at Greensburg, and the Pennsylvania Department of Mines made available the public records of these offices. Aerial photographs of the county were loaned by the Pennsylvania Department of Commerce. The author was assisted during the field mapping and collecting of mine and drill-hole records by Andrew Yelenosky, Thomas M. Kehn, and George W. Moore.

\section{STRATIGRAPHY}

All the bedrock exposed in Beaver County is of Pennsylvanian age. The regional dip of these rocks is about $1^{\circ} \mathrm{SW}$, so that the oldest rocks crop out at the lowest elevations in the northern part of the county, and the youngest rocks are exposed on the highest hills in the southern part of the county. The aggregate thickness of exposed Pennsylvanian rocks is about 1,000 feet; these rocks include, from oldest to youngest, the Pottsville, Allegheny, Conemaugh, and Monongahela Formations (pl. 1). The lowest part of the Pottsville Formation, about 50 feet thick, is not exposed in Beaver County, but drillhole records show that the formation rests on rocks of Mississippian age; only the lowest part of the Monongahela Formation, about 50 feet thick, is exposed on the hills in the southern part of the county. The distribution of these formations in Beaver County is shown on the geologic map (pl.2).

Unconsolidated sediments of Quaternary age overlie the rocks of Pennsylvanian age in some highland areas and along the larger streams in parts of Beaver County. These sediments include glacial drift, outwash gravels, terrace deposits, and alluvium, but they are not pertinent to this report and are not shown on the geologic map.

The common types of rock in the Pennsylvanian formations in Beaver County are sandstone, siltstone, shale, limestone, underclay, and coal. Sandstone is the most abundant rock type and forms cliffs and ledges in places; it is commonly thin bedded and micaceous, and weathers brown. Siltstone and shale, which are about equal in abundance, are commonly interbedded; both are generally gray to dark gray, and weather brown, although red and green shales are common in the Conemaugh Formation. Locally, the shale contains abundant 
comminuted carbonaceous material and fossils of leaves and plant stems; nodules and thin beds of ironstone also are common in some carboncecous shale units. Both marine and fresh-water limestone units are present. The marine limestone is lenticular or massive and is generally gray, coarsely crystalline, and fossiliferous; the freshwater limestone is thin bedded or nodular, and is generally gray, microcrystalline, nonfossiliferous, and-in many places-conglomeratic or brecciated. The underclay lies beneath coal beds, is light to dark gray, and commonly contains impressions of roots. The coal beds, which are irregular in thickness but generally less than 3 feet thick, commonly extend throughout the county, but, locally, are replaced laterally by coaly shale, or are cut out by channel-sandstone deposits.

Emphasis in this discussion is placed on the stratigraphic relations of each coal bed to overlying and underlying rock units. The status of reserves and mining of each of these beds is included in the last part of the report, and the thicknesses of the coal beds are shown on plate 5 .

\section{POTTSVILIE FORMATION}

The name Pottsville Seral Conglomerate was given by Lesley (1876, p. 221-227) to a massive conglomeratic sandstone, 1,200 feet thick, in the anthracite region of eastern Pennsylvania. The name Pottsville formation has been applied (White, 1878, p. 66; Woolsey, 1906, p. 8; DeWolf, 1929, p. 47) to rocks in western Pennsylvania that are stratigraphically equivalent to the Pottsville Seral Conglomerate. The Pottsville Formation in the Beaver River valley of western Pennsylvania is $300-350$ feet thick. It is underlain by Mississippian rocks, and overlain by the Allegheny Formation. Only the upper 250 feet of the formation is exposed in Beaver County, along the valleys of Beaver River and Connoquenessing Creek in the northern part of the county (pl.2).

The Pottsville Formation of Early Pennsylvanian age may be divided into the following units (fig. 1), listed in ascending order: The Sharon coal bed, Connoquenessing Sandstone Member (this member is composed of a lower sandstone bed, an unnamed shale bed, Quakertown coal bed, and an upper sandstone bed), an unnamed shale and siltstone, Mercer Shale Member, an unnamed shale, Homewood coal bed, an unnamed shale, Homewood Sandstone Member, and an unnamed shale. Only those units of economic importance or those helpful in determining stratigraphic position are discussed on the follow pages.

The Pottsville Formation contains five thin coal beds (pls. 1, 3, and 4), in ascending order, as follows: The Sharon, Quakertown, Lower Mercer, Upper Mercer, and Homewood. The Sharon coal bed, 0-1 
foot thick and a few feet above the base of the formation, is not exposed in Beaver County. The other coal beds are exposed in the valley of the Beaver River, north of the town of Homewood. The Quakertown, named by White $(1879$, p. 65$)$, is about 50 feet above the base of the Pottsville and is 3-6 inches thick in Beaver County. The Lower and Upper Mercer coal beds (Rogers, 1858, p. 475) are generally associated with shale and thin marine limestone beds near the middle of the Pottsville Formation. At a few places (for example, sec. 14, pl. 4) three thin coal beds are in this interval and have been termed the Upper, Middle, and Lower Mercer coal beds; where observed at a few poor outcrops, these beds are less than 1 foot thick. The uppermost coal bed, the Homewood (DeWolf, 1929, p. 50), is generally a few feet below a thick sandstone and 30-50 feet below the top of the Pottsville Formation; the Homewood coal bed ranges from $0-30$ inches in thickness.

In addition to the coal beds, several other rock units in the Pottsville Formation are distinctive and widespread and have been given member names. Three of these are exposed in Beaver County: the Connoquenessing Sandstone Member, the Mercer Shale Member, and the Homewood Sandstone Member. The Connoquenessing, the oldest of these three members, has an average thickness of 70 feet and is made up of a lower sandstone bed, a middle shale unit containing the thin Quakertown coal bed, and an upper sandstone unit. The Mercer Shale Member overlies the Connoquenessing Sandstone Member, but is poorly exposed in Beaver County; the member generally is a darkgray shale 20-30 feet thick containing the Iower and Upper Mercer coal beds and two lenticular fossiliferous marine limestone beds. The Mercer Shale Member is separated from the Homewood Sandstone Member by a shale unit, unnamed in this report, that is lighter colored than the Mercer; this shale unit, which is $20-40$ feet thick and has the Homewood coal bed in its upper part, was included in the Homewood Sandstone Member by DeWolf (1929). The Homewood Sandstone Member of this report is limited to the thin-bedded to massive sandstone in the upper part of the Pottsville that generally is about 25 feet thick. At the town of Homewood, on the west side of the Beaver River, this sandstone appears to be 155 feet thick. The abnormally thick sandstone at Homewood, however, may represent a merging of the Homewood and Connoquenessing Members of the Pottsville Formation with the Clarion Sandstone Member of the Allegheny Formation. The uppermost unit of the Pottsville in some areas is an unnamed shale 8 to 10 feet thick that separates the Homewood Sandstone Member from the underclay of the Brookville coal bed in the overlying Allegheny Formation; in other areas the shale and underclay are very 
thin and the Brookville coal bed and Homewood Sandstone Member are almost in direct contact (secs. 14 and 16, pl. 6).

\section{ALLEGHENY FORMATION}

The name Allegheny series was first used by Rogers (1840, p. 50) for all strata exposed along the Allegheny River in Allegheny, Armstrong, and Clarion Counties, Pa. (fig. 1). Subsequently, Stevenson $(1873$, p. 16) restricted the stratigraphic term Allegheny to those rocks between the top of his Pottsville Series and the base of the Mahoning Sandstone in his overlying Conemaugh series. In general, this restriction has been adopted, and the Allegheny Formation, as used here, is bounded by the base of the underclay of the Brookville coal bed and by the top of the Upper Freeport coal bed (fig. 3). The Allegheny Formation in Beaver County is about 300 feet thick and is widely exposed in all the stream valleys in the northern half of the county and in the valley of the Ohio River (fig. 2).

The Allegheny Formation of probable Middle Pennsylvanian age is divisible into the following units (pl. 1), listed in ascending order, as follows: The Brookville coal bed and its underclay, an unnamed shale, Clarion coal bed, and unnamed shale, Clarion Sandstone Member, Scrubgrass coal bed and its underclay, an unnamed shale, Vanport Limestone Member, an unnamed shale, Kittanning Sandstone Member, an unnamed shale, Lower Kittanning coal bed, an unnamed shale, Middle Kittanning coal bed, an unnamed shale, unnamed siltstone and sandstone, Upper Kittanning coal bed, Freeport Sandstone Member, Lower Freeport Limestone Member, an unnamed clay, Lower Freeport coal bed, an unnamed shale, Butler Sandstone Member, Upper Freeport Limestone Member, Upper Freeport coal bed and its underclay. Those units of economic importance or those helpful in determining stratigraphic position are discussed on the following pages.

The Allegheny Formation contains eight coal beds in Beaver County. They are, in ascending order, as follows: The Brookville; Clarion; Scrubgrass; Lower, Middle, and Upper Kittanning; and Lower and Upper Freeport (pls. 1, 3, and 4). The Brookville, Clarion, and Scrubgrass (Rogers, 1858, p. 474-477, p. 490, and p. 491, respectively) are thin coal beds in the lower 50 foet of the Allegheny Formation (sec. 18, pl. 4) ; each is generally 1 foot or less thick and is separated by variable thicknesses of shale and sandstone. Some doubt exists as to the correctness of the application of these three names to these three coal beds in Beaver County because elsewhere their correlation is uncertain (for example, see Wanless, 1939, p. 101; Graeber and Foose, 1942, p. 50-55); however, these names and correlations are tentatively adopted here. 
The Brookville coal bed, though very thin and discontinuous, commonly lies on or a few feet above the Homewood Sandstone Member of the Pottsville; the base of this coal bed or its underclay marks the base of the Allegheny Formation. The Clarion coal bed is persistent in Beaver County and is generally 10-20 feet above the base of the Allegheny Formation; it is typically 12 inches thick along the Beaver River (sec. 7A, pl. 3). The Scrubgrass coal bed is somewhat lenticular and is as much as 20 inches thick (sec. 18, pl. 4). It occurs about 40 feet above the base of the Allegheny Formation and a few feet below the distinctive Vanport Limestone Member.

The Lower, Middle, and Upper Kittanning coal beds are in an interval 50-75 feet thick near the middle of the Allegheny Formation (pls. 1, 2, 3, and 4). The name Kittanning was first used by Rogers (1858), p. 474-477, 491) to designate a coal bed cropping out at Kittanning on the Allegheny River in Armstrong County, Pa. When a second coal bed was found in that area, White $(1879$, p. 322$)$ called the lower of the two coal beds the Lower Kittanning and the other the Upper Kittanning. Subsequently, Chance $(1879$, p. 23, 24) called attention to the confusion in identifying White's Lower and Upper Kittanning coals beds in Butler County because a third coal bed is present there. Chance then named these beds the Lower, Middle, and Upper Kittanning coal beds, the names now used in western Pennsylvania.

The Lower Kittanning coal bed is about 75 feet stratigraphically above the Scrubgrass coal bed; it ranges from 0 to 3 feet in thickness and commonly contains one or more laterally persistent clay partings. This coal bed crops out in much of the northern half of Beaver County and has been penetrated by oil wells (wells $3-8$ and 14 on pl. 1) drilled in the south half of county, where its average thickness is estimated to be 15 inches. The few analyses (table 5) of the Lower Kittanning indicate that it contains about 2 percent sulfur and 7 percent ash.

The Middle Kittanning coal bed is about 40 feet above the Lower Kittanning coal bed and is generally thinner than the Lower Kittanning. In most places in Beaver County the Middle Kittanning is about 2 feet thick, but in the central part of the county, in the vicinity of Brady Run and the junction of the Beaver and Ohio Rivers, the average thickness of the coal bed is slightly less than 14 inches. The thickness of the coal in the southern and southeastern parts of the county is estimated to be 15-24 inches, based on sparse well-record data (wells 1, 5, 7, and 14 on pl. 1). The Middle Kittanning coal contains an average of 2.4 percent sulfur in moisture-free samples; the ash content ranges from 2.0 to 11.4 percent, indicating a fairly wide variance in quality of coal (table 5 ). 
The Upper Kittanning coal bed, which lies from 20 to 30 feet above the Middle Kittanning, is generally less than 6 inches thick and is discontinuous throughout the county. However, in a few square miles in northwest Beaver County near Darlington and Cannelton, the Upper Kittanning coal bed consisted of 6-12 feet of cannel coal, underlain by 6-12 inches of bituminous coal and overlain by canneloid shale as much as 6 feet thick. This deposit, described by DeWolf $(1929$, p. 41), is now mined out, and all entrances to the many mines in the deposit have collapsed.

The Lower and Upper Freeport coal beds are in the upper part of the Allegheny Formation, separated by about 45 feet of sandstone and shale. The top of the Upper Freeport marks the contact between the Allegheny Formation and the overlying Conemaugh Formation. The names of the two coal beds have been informally used since 1837 . (See p. xv of "Preface" by J. P. Lesley in White, 1878.) They were formally applied by Rogers $(1858$, p. 476,595$)$ to outcrops of these two beds along the Allegheny River in southwestern Armstrong County at Freeport, Pa.

The Lower Freeport coal bed has a wide range in both thickness and quality in Beaver County. In the southern and eastern parts of the county the coal bed is less than 14 inches thick or is absent. In the northwestern part of the county, where the bed is thickest, the range in thickness is from 14 to 48 inches, but there the coal bed includes thick partings of shale and masses of canneloid shale. The rank of coal in the Lower Freeport is variable, ranging from highvolatile A to high-volatile $\mathrm{C}$.

The Upper Freeport coal bed, which underlies most of Beaver County, has an average thickness of 36 inches and is generally of good quality. The bed thickens from less than 14 inches in the southeastern and eastern parts of the county (drill holes 2-4, and 7 on pl. 2) to more than 80 inches in the northwestern part. The coal is high-volatile $\mathbf{A}$ bituminous in rank, and the average sulfur and ash content of six moisture-free samples is 2.3 and 7.2 percent, respectively (table 4).

Of the rocks separating the coal beds in the Allegheny Formation in Beaver County, the Vanport Limestone Member is the most distinctive and the most useful in differentiating the several coal beds. This marine limestone member, which is generally about 10 feet thick and commonly crops out in stream valleys, is about 50-60 feet above the base of the formation and separates the sandstone and shale sequence containing the three thin Brookville, Clarion, and Scrubgrass coal beds from the middle and upper parts of the formation containing the three Kittanning coal beds and the two Freeport coal beds. 
The Allegheny Formation also has four sandstone members (pl. 1), but these are difficult to differentiate. in the field except by their stratigraphic position relative to the Vanport Limestone Member and the coal beds. Further, the thickness and distribution of these sandstone units are erratic, and their lateral position is commonly occupied entirely, or in large part, by shale or siltstone. The lowest sandstone member, stratigraphically, is the Clarion Sandstone Member, which is the thin-bedded sandstone about 10 feet thick lying between the. Clarion and Scrubgrass coal beds and, thus, below the Vanport Limestone Member. In the 30-50-foot interval between the Vanport Limestone Member and the Lower Kittanning coal bed is a lenticular sandstone unit, the Kittanning Sandstone Member, which has an average thickness of about 20 feet. The Freeport Sandstone Member occupies almost the entire 100-foot stratigraphic interval between the Upper Kittanning and the Lower Freeport coal beds. This sandstone member can commonly be identified in the field by its abundance of clay pellets, streaks of coaly material, and mica flakes. The uppermost sandstone member in the Allegheny Formation is the Butler, which in places occupies the entire 30 - to 50 -foot interval between the Lower Freeport coal bed and the underclay of the Upper Freeport coal bed.

In some parts of Beaver County, the Lower and Upper Freeport coal beds each have a thin commonly brecciated fresh-water limestone beneath their underclay, called the Lower Freeport Limestone and Upper Freeport Limestone Members, respectively. Each of these members is discontinuous, however, and rarely is more than 2 feet thick.

Many shale and siltstone units and several units having interbedded siltstone and sandstone are interspersed through the Allegheny Formation and have not been given formal stratigraphic names (pl. 1). Each of these unnamed units is generally characterized by variable lithology-both laterally and vertically, and outcrops of these units are relatively rare.

\section{CONEMAUGH FORMATION}

The name Conemaugh Series was first applied by Platt $(1875$, p. 8$)$ to rocks exposed along the Conemaugh River in Indiana and Westmoreland Counties, Pa. (fig. 1). Woolsey (1906, p. 16) termed the Conemaugh a formation in his report on Beaver County, and his usage is followed here. The Conemaugh Formation in Beaver County is about 500 feet thick and is distinguished from the underlying Allegheny Formation and the overlying Monongahela Formation by a greater amount of siltstone and shale, including red and green shale. 
The lower contact of the Conemaugh is at the top of the Upper Freeport coal bed of the Allegheny Formation, and the upper contact is at the base of the underclay of the Pittsburgh coal bed of the Monongahela Formation. The sediments in the Conemaugh Formation form the bedrock in most of Beaver County (pl. 2).

The Conemaugh Formation of probable Middle and Late Pennsylvanian age is composed of the following units (pl. 1), listed in ascending order: An unnamed shale, Mahoning Sandstone Member, Mahoning coal bed and its underclay; an unnamed sandstone and shale, an unnamed limestone, New Galilee Clay Shale of DeWolf (1929), an unnamed shale, Brush Creek coal bed and its underclay, an unnamed sandstone and shale, an unnamed coal bed, Brush Creek Limestone Member, Buffalo Sandstone Member, Bakerstown coal bed, "Pittsburgh red beds" of local usage, Harlem coal bed, Ames Limestone Member, "Washington reds" of local usage, Elk Lick coal bed, Morgantown Sandstone Member, an unnamed shale and sandstone, Lower Pittsburgh Limestone Member, an unnamed shale, Upper Pittsburgh Limestone Member, and an unnamed shale. Those units of economic importance, or those helpful in determining stratigraphic position are discussed on the following pages.

The Conemaugh Formation contains five coal beds; they are, in ascending order, the Mahoning, Brush Creek, Bakerstown, Harlem, and Elk Lick. The Mahoning coal bed was named by White (1891, p. 96) but was later referred to as the East Palestine by DeWolf (1929, p. 33-34), who questioned White's correlation of the Mahoning across Beaver County. The name Mahoning is used in preference to East Palestine by the Pennsylvania Topographic and Geologic Survey and by the Ohio Geological Survey and is so used here. The Brush Creek coal bed was named by White $(1878$, p. 35$)$ for exposures of the coal on Brush Creek, just east of Beaver County, in southwestern Butler County. The Bakerstown coal bed was also named by White (1878, p. 162), for Bakerstown, Allegheny County, Pa., but the correlation of this bed in Beaver County with that at the type locality is uncertain. The Harlem coal bed, formerly known as the Platt coal, was named by Newberry (1874, p. 156-157) for the area where it was once mined, near Harlem Springs in Carroll County, Ohio. The Elk Lick coal bed was named for the village of Elk Lick, Somerset County, Pa. (Lesley, 1856, p. 92).

The Mahoning is the lowest coal bed in the Conemaugh Formation; it is less than 14 inches thick everywhere in Beaver County except in the northwestern part, where its average thickness is about 31 inches. The bed is $36-47$ inches thick in north-central Darlington Township, 31-36 inches thick in western Darlington Township, and 
14-29 inches thick in southern Darlington Township and in the northwestern part of South Beaver Township. In this northwestern part of the county, the Mahoning coal crops out high on the hill slopes and is of good quality. To the west, in Columbiana County, Ohio, the coal bed is widespread but of variable thickness (Stout and Lamborn, 1924 , p. $245,247,298$ ). The coal is estimated to contain 1.7 percent sulfur and 7.0 percent ash, based on one analysis (table 4).

The Brush Creek coal bed commonly crops out near the tops of hills in northern and central Beaver County and in the valleys in the southern part of the county but is generally thin and discontinuous. In the eastern part of the county, particularly in southeastern New Sewickley Township, the coal bed is 14-30 inches thick and is of fair quality.

The Bakerstown, Harlem, and Elk Lick coal beds generally are thin lenticular beds that crop out only on the hills in the southern part of the county. Woolsey (1906, p. 18-19) reported the Bakerstown coal to be 2-7 feet thick southeast of Georgetown and the Platt (Harlem) coal to be about 1 foot thick near Hookstown; Stevenson (1876, p. 338) stated that the Elk Lick coal bed is $2-3$ feet thick in Independence and Greene Townships. The author was unable to verify these thicknesses.

The general lithology and sequence of beds in the lower part of the Conemaugh Formation that contains the Mahoning and Brush Creek coal beds are difficult to differentiate from the underlying Allegheny Formation (pl. 1). However, near the base of the Conemaugh is the Mahoning Sandstone Member-a widespread, generally massive coarse-grained sandstone as much as 55 feet thick that forms cliffs in some areas. The Mahoning coal bed is about 20 feet stratigraphically above the top of this sandstone and is separated from the sandstone by shale, and by a thin limestone which is the Mahoning Limestone bed of the Mahoning Sandstone Member of White (1891). The Mahoning coal bed, in turn, is separated from the overlying Brush Creek coal bed by clay shale, shale, and sandy shale about 45 feet thick; the New Galilee Clay Shale of DeWolf (1929) is a flintclay unit in this interval that is 5-20 feet thick and 10-20 feet below the Brush Creek coal bed. The Brush Creek coal bed is separated from the Bakerstown coal bed mainly by the Buffalo Sandstone Member, which is as much as 80 feet thick; the marine Brush Creek Limestone Member, which is only a few feet thick, is immediately below this sandstone and about 10 feet above the Brush Creek coal bed.

The most useful stratigraphic marker bed in the Conemaugh Formation is the marine Ames Limestone Member, which is near the middle of the formation ( $\mathrm{pl} .1$ ). This limestone is thin, generally less than 
5 feet thick, but is widespread in southern Beaver County and is easily recognized by its position between two units of red shale, which are locally called the "Pittsburgh red beds" (below) and the "Washington reds" (above). The positions of the Bakerstown, Harlem, and Elk Lick coal beds are readily determined with reference to the Ames and these red beds; the Bakerstown is just below the "Pittsburgh red beds", the Harlem is below the Ames, and the Elk Creek is above the "Washington reds".

The upper third of the Conemaugh Formation, between the Elk Lick coal bed and the base of the Pittsburgh coal bed, is composed of the thick Morgantown Sandstone Member and an unnamed unit of shale and shaly sandstone which includes the Lower and Upper Pittsburgh Limestone Members. The latter two members generally are only a foot thick and are about 30 and 15 feet below the Pittsburgh coal bed, respectively.

\section{MONONGAHELA FORMATION}

As currently designated, the Monongahela Formation is only a part of what Rogers (1840, p. 150) originally described as the Monongahela Series in the valley of the Monongahela River. The Monongahela Series of Rogers included the presént Conemaugh and Monongahela Formations as well as some rocks of Permian age. Stevenson (1873) renamed the Monongahela Series the Monongahela River Series and excluded from it all strata above the top of the Waynesburg Sandstone and below the underclay of the Pittsburgh coal bed. Woolsey (1906, p. 20) dropped the word "River" from the formal name of the rock sequence in western Pennsylvania and called it the Monongahela Formation. Only the lowest part of the Monongahela, 58 feet or less, is in Beaver County, capping several hills in Hanover and Hopewell Townships in the southern part of the county (pl. 2).

The lowest part of the Monongahela Formation of Late Pennsylvanian age may be divided (pl. 1), in ascending order, into the Pittsburgh coal bed and its underclay, an unnamed shale, the Pittsburgh Rider coal bed, and an unnamed shale that contains a coarse sandstone, approximately 5 feet thick, 20 feet above the Pittsburgh Rider coal bed.

The only coal beds of the Monongahela Formation in Beaver County are the Pittsburgh and Pittsburgh Rider, which were named for outcrops near the city of Pittsburgh (Lesley, 1856, p. 84). In outliers near Frankfort Springs at the south edge of the county, the Pittsburgh coal bed ranges from 4 to 5 feet in thickness, considerably thinner than in counties to the south and southeast, where it is 10-15 feet thick. The rank of the Pittsburgh coal in Beaver County is not known, but in adjacent counties it is high-volatile $\mathrm{A}$ bituminous coal. 
The Pittsburgh Rider coal bed, lying 10-20 feet above the Pittsburgh coal bed, is about 2 feet thick in the outliers of southern Beaver County but contains many shaly partings. Dark-gray shale, containing some coaly shale, separates the two coal beds. Overlying the Pittsburgh Rider coal bed and capping a few knobs is a shale unit containing some sandstone that is the youngest and stratigraphically highest unit of Pennsylvanian age in Beaver County.

\section{STRUCTURE}

- In general, the strata of Pennsylvanian age in Beaver County have an almost imperceptible dip of about $1^{\circ} \mathrm{SW}$. Locally, however, these strata have been gently warped into broad open folds, gentle domes, and shallow basins that are generally elongated in a northeastsouthwest direction; the maximum change in elevation of a datum across these flexures rarely exceeds 100 feet, and the strata rarely dip more than $3^{\circ}$.

The Homewood anticline is the most prominent structural feature in Beaver County. The axis of this anticline trends northeastward from the vicinity of Smiths Ferry toward Homewood, where it can be easily traced on the surface northeastward into Lawrence County in the vicinity of Ellwood City. The maximum amplitude of the Homewood anticline is about 100 feet. The Darlington syncline is northwest of and complimentary to the Homewood anticline. The axis of this relatively symmetrical downfold trends sinuously northeastsouthwest across the northwestern part of Beaver County near the town of Darlington.

In the central and southern parts of the county southeast of the Homewood anticline, the strata are flexed into several poorly defined domes and basins. In southeastern Beaver County, east of the Ohio River, are the West Middleton syncline, Crows Run anticline, and Sewickley syncline; these structural features, which are smaller than the Homewood and Darlington folds, terminate on the north in the vicinity of Brush Creek.

\section{COAL RESERVES}

Twenty-one coal beds crop out in Beaver County. The stratigraphic position of these coal beds and the intervals between them are shown in the generalized section for Beaver County (pl. 1). Of these coal beds, the Lower Kittanning, Middle Kittanning, Lower Freeport, and Upper Freeport contain large reserves. The lenticular Mahoning and Brush Creek coal beds contain relatively small reserves. The Upper Kittanning coal bed, though widespread, is relatively thin in most parts of the county, and the localized areas of thick coal in the Upper Kittanning have been mined out. The Pittsburgh coal, 
which is confined to several higher hills in southern Beaver County, also has been largely depleted through intensive minning.

The outcrops of these eight coal beds are shown on the geologic map (pl. 2), and maps showing outcrop and thickness have been prepared for each bed (pl. 5). The other coal beds that crop out in Beaver County are less than 14 inches thick and impure and are not considered in estimates of reserves.

\section{SUMMARY OF RESERVES}

The original reserves of coal in Beaver County totaled 2,517 million tons, of which 419 million is classified as measured, 1,062 million tons as indicated, and 1,036 million tons as inferred. Included in the 419 million tons of measured coal is 28 million tons of coal mined or lost in mining; the remaining measured reserves are 391 million tons as of January $1,1956$.

Remaining measured reserves of 391 million tons, plus indicated reserves of 1,062 million tons and inferred reserves of 1,036 million tons give total remaining reserves of 2,489 million tons as of January 1 , 1956.

The distribution of these reserves in Beaver County, by quadrangle, is given in table 1.

Lower Kittanning coat bed.--The original reserves of coal in the Lower Kittanning coal bed totaled 837 million tons, of which 108.3 million tons is classified as measured, 321.8 million tons as indicated, and 406.9 million tons as inferred (table 1 ).

Classification by thickness categories shows that 705 million tons of the reserves in the Lower Kittanning coal is in areas where the bed ranges in thickness from 14 to 28 inches, 131 million tons where it ranges in thickness from 28 to 42 inches, and 0.3 million tons where the coal bed is more than 42 inches thick. The areal distribution and thickness of the Lower Kittanning coal bed are shown in plate 5 .

In terms of contained reserves, the Lower Kittanning is the most important coal bed in Beaver County.

Middle Kittanning coal bed.-The original reserves of coal in the Middle Kittanning coal bed totaled 630 million tons, of which 72.8 million tons is classified as measured, 321.8 million tons as indicated, and 283.7 million tons as inferred (table 1). Classification by thickness categories shows that 568 million tons of coal is in areas where the bed is $14-28$ inches thick, 61 million tons where it is $28-42$ inches thick, and 1.1 million tons where it is more than 42 inches thick. The areal distribution and thickness of the Middle Kittanning coal bed are shown in plate 5. The Middle Kittanning in Beaver County. ranks second to the Lower Kittanning coal bed in quantity of minable reserves. 
Table 1.-Summary of estimated original coal reserves, in millions of short tons, in Beaver County, Pa., by quadrangle and by bed

\begin{tabular}{|c|c|c|c|c|c|c|c|c|c|c|c|c|c|c|c|}
\hline & \multicolumn{4}{|c|}{$\begin{array}{l}\text { Measured reserves in beds of } \\
\text { indicated thickness }\end{array}$} & \multicolumn{4}{|c|}{$\begin{array}{l}\text { Indicated reserves in beds of } \\
\text { indicated thickness }\end{array}$} & \multicolumn{3}{|c|}{$\begin{array}{l}\text { Inferred reserves in beds } \\
\text { of indicated thickness }\end{array}$} & \multicolumn{3}{|c|}{$\begin{array}{c}\text { Total, all categories, in } \\
\text { beds of indicated thickness }\end{array}$} & \multirow{2}{*}{$\begin{array}{c}\text { Grand } \\
\text { total }\end{array}$} \\
\hline & $\begin{array}{l}\text { 14-28 } \\
\text { inches }\end{array}$ & \begin{tabular}{|c|}
$28-42$ \\
inches
\end{tabular} & $\underset{\text { inches }}{>42}$ & Total & $\begin{array}{l}\text { 14-28 } \\
\text { inches }\end{array}$ & $\begin{array}{c}28-42 \\
\text { inches }\end{array}$ & inches & Total & $\begin{array}{l}14-28 \\
\text { inches }\end{array}$ & $\begin{array}{c}28-42 \\
\text { inches }\end{array}$ & Total & $\begin{array}{l}14-28 \\
\text { inches }\end{array}$ & $\begin{array}{c}28-42 \\
\text { inches }\end{array}$ & inches & \\
\hline \multicolumn{16}{|c|}{ Quadrangles } \\
\hline $\begin{array}{l}\text { Aliquippa and Clinton } \\
\text { Ambridge and Baden } \\
\text { Beaver-- } \\
\text { Burgettstown and Hookstown } \\
\text { Steubenville NE and Wellswille SE } \\
\text { Columbiana SE and New Castle SW } \\
\text { Midland and Wellsville NE } \\
\text { New Castle SE } \\
\text { Zelienople SW }\end{array}$ & $\begin{array}{r}7.61 \\
9.69 \\
45.50 \\
31.13 \\
43.30 \\
23.54 \\
31.05 \\
17.81\end{array}$ & $\begin{array}{r}2.81 \\
2.54 \\
12.81 \\
15.12 \\
47.81 \\
40.50 \\
32.02 \\
11.19\end{array}$ & $\begin{array}{r}0.29 \\
2.50 \\
20.03 \\
13.27 \\
6.99 \\
1.10\end{array}$ & $\begin{array}{r}10.71 \\
12.23 \\
58.31 \\
48.75 \\
111.14 \\
77.31 \\
70.06 \\
30.10\end{array}$ & $\begin{array}{r}39.77 \\
79.11 \\
94.26 \\
56.03 \\
150.60 \\
163.94 \\
71.95 \\
76.58\end{array}$ & $\begin{array}{r}3.16 \\
5.67 \\
7.21 \\
44.73 \\
60.66 \\
103.40 \\
38.01 \\
21.47\end{array}$ & $\begin{array}{r}18.46 \\
8.09 \\
19.03\end{array}$ & $\begin{array}{r}42.93 \\
84.78 \\
101.47 \\
100.76 \\
229.72 \\
275.43 \\
128.99 \\
98.05\end{array}$ & $\begin{array}{r}149.77 \\
199.91 \\
47.84 \\
286.55 \\
40.33 \\
127.47 \\
10.79 \\
\mathbf{4 4 . 3 5}\end{array}$ & $\begin{array}{r}3.21 \\
68.68 \\
3.74 \\
52.10 \\
-1.05\end{array}$ & $\begin{array}{r}149.77 \\
203.12 \\
47.84 \\
355.23 \\
44.07 \\
179.57 \\
10.79 \\
45.40\end{array}$ & $\begin{array}{l}197.15 \\
288.71 \\
187.60 \\
373.71 \\
234.23 \\
314.95 \\
13.79 \\
138.74\end{array}$ & $\begin{array}{r}5.97 \\
11.42 \\
20.02 \\
128.53 \\
112.21 \\
196.00 \\
70.03 \\
33.71\end{array}$ & \begin{tabular}{|r|}
0.29 \\
2.50 \\
38.49 \\
21.36 \\
26.02 \\
1.10
\end{tabular} & $\begin{array}{l}203.41 \\
300.13 \\
207.62 \\
504.74 \\
384.93 \\
532.39 \\
209.84 \\
173.55\end{array}$ \\
\hline Total & 209.63 & 164.80 & 44.18 & 418.61 & 732.24 & 284.31 & 45.58 & $1,062.13$ & $\begin{array}{l}907.01 \\
\end{array}$ & 128.78 & $1,035.79$ & $1,848.88$ & $\overline{577.89}$ & 89.76 & $\overline{2,516.53}$ \\
\hline
\end{tabular}

Coal beds

[Shown on pl. 5]

\begin{tabular}{|c|c|c|c|c|c|c|c|c|c|c|c|c|c|c|c|}
\hline \multicolumn{14}{|l|}{ Pittsburgh $_{\ldots}$} & \multirow{2}{*}{0.29} & \multirow{7}{*}{$\begin{array}{r}0.29 \\
18.36 \\
13.09 \\
595.38 \\
420.96 \\
1.21 \\
630.27 \\
836.97\end{array}$} \\
\hline Brush Creek & 0.64 & 1.01 & & $\begin{array}{l}0.29 \\
1.65\end{array}$ & $2.60^{-}$ & 3.18 & & 5.78 & 7.72 & 3.21 & 10.93 & 10.96 & 7.40 & & \\
\hline Mahoning & 1.80 & 8. 63 & 1.04 & 11.47 & .82 & .80 & & 1.62 & & & & 2.62 & 9. 43 & 1.04 & \\
\hline $\begin{array}{l}\text { Upper Freeport. } \\
\text { Lower Freeport. }\end{array}$ & $\begin{array}{l}71.49 \\
16.33\end{array}$ & $\begin{array}{l}83.53 \\
11.38\end{array}$ & 40.22 & $\begin{array}{r}195.24 \\
27.71\end{array}$ & $\begin{array}{l}101.83 \\
123.65\end{array}$ & $\begin{array}{r}139.39 \\
48.76\end{array}$ & 45.58 & $\begin{array}{l}286.80 \\
172.41\end{array}$ & $\begin{array}{r}54.22 \\
194.61\end{array}$ & $\begin{array}{l}59.12 \\
26.23\end{array}$ & $\begin{array}{l}113.34 \\
220.84\end{array}$ & $\begin{array}{l}227.54 \\
334.59\end{array}$ & $\begin{array}{r}282.04 \\
86.37\end{array}$ & 85.80 & \\
\hline Upper Kittanning.- & & & 1.21 & 1.21 & & & & & & & & & & 1.21 & \\
\hline Middle Kittanning & $48.30^{-}$ & 23. 39 & 1.10 & 72.79 & 236.82 & 36.92 & - & 273.74 & 282 & 76 & $28 \overline{3}$ & 568 & 61.07 & 1.10 & \\
\hline Lower Kittanning.. & 71.07 & 36.86 & .32 & 108.25 & 266.52 & 55.26 & 10 & 321.78 & 367.48 & 39.46 & 406.94 & 705.07 & 131.58 & .32 & \\
\hline Total_ & 209.63 & 164.80 & 44.18 & 418.61 & 732.24 & 284.31 & 45.58 & $1,062.13$ & 906.01 & 128.78 & $1,035.79$ & $1,848.88$ & 577.89 & 89.76 & $2,516.53$ \\
\hline
\end{tabular}


Upper Kittanning coal bed.-The original reserves of coal in the Upper Kittanning coal bed totaled 1.2 million tons, all of which has been mined or lost in mining.

Lower Freeport coal bed.-The original reserves of coal in the Lower Freeport coal bed totaled 421.0 million tons, of which 27.7 million tons is classified as measured, 172.4 million tons as indicated, and 220.8 million tons as inferred (table 1 ).

Classification by thickness categories shows that 334.6 million tons is in areas where the coal bed is 14-28 inches thick and 86.4 million tons where it is $28-42$ inches thick. The areal distribution and thickness of the Lower Freeport coal bed are shown in plate 5 .

Upper Freeport coal bed.-The original reserves of coal in the Upper Freeport bed totaled 595 million tons, of which 195.2 million tons is classified as measured, 286 million tons as indicated, and 113.3 million tons as inferred (table 1).

Classification by thickness categories shows that 227.5 million tons is in areas where the coal bed is $14-28$ inches thick, 282 million tons where it is $28-42$ inches thick, and 85.8 million tons where it is more than 42 inches thick. The area distribution and thickness of the Upper Freeport coal bed are shown in plate 5.

Of the coal beds for which reserves were calculated, the Upper Freeport contained the largest thickness of thick coal (42 inches or more). Through intensive mining, however, much of the coal within this thickness category has been removed.

Mahoning coal bed.-The original reserves of coal in the Mahoning totaled 13 million tons, of which 11.5 million tons is classified as measured and 1.6 million tons as indicated (table 1). Classification by thickness categories shows that 2.6 million tons is in areas where the coal bed is 14-28 inches thick, 9.4 million tons where it it $28-42$ inches thick, and 1 million tons where it is more than 42 inches thick.

The Mahoning coal bed is of minable thickness (more than 14 inches thick) only in the extreme northwestern part of Beaver County (pl. 5).

Brush Creek coal bed.-The original reserves of coal in the Brush Creek coal bed totaled 18.3 million tons, of which 1.6 million tons is classified as measured, 5.8 million tons as indicated, and 10.9 million tons as inferred (table 1). Classification by thickness categories shows that 10.9 million tons is in areas where the thickness of the coal bed is 14-28 inches and 7.4 million tons where the thickness is 28-42 inches.

The Brush Creek coal bed is of minable thickness only in the eastern part of the county (pl.5). 
Pittsburgh coal bed.-The original reserves of coal in the Pittsburgh coal bed totaled 0.3 million tons, but the coal in this bed has been largely mined out. Plate 5 shows the distribution of original reserves for the Pittsburgh.

\section{METHODS USED IN PREPARING ESTIMATES OF RESERVES}

Estimating coal reserves of any area requires certain assumptions as to thickness, areal extent, correlation of the coal beds, and weight of the coals. An estimate, therefore, is of value only to the extent that the definitions and procedures used in its preparation are explained and understood. Furthermore, estimates of coal reserves, to be of greatest usefulness, must be arranged into categories based on the characteristics of the coal and on the abundance and reliability of the data used in preparing the estimate. Criteria used in preparing the estimate in this report and the categories into which the estimate is divided are described below.

\section{CLASSIFICATION ACCORDING TO CHARACTERISTICS OF THE COAL}

Characteristics of the coal considered in calculating reserves are rank of the coal, thickness of beds, and thickness of overburden. Weight of the coal, an essential factor in computing tonnage, is largely a function of rank and ash content.

American coals are ranked in accordance with the standard classification of the American Society for Testing Materials (table 2). Most of the coal in Beaver County is of high-volatile A bituminous rank.

The average weight of bituminous coal of low to medium ash content, as determined by many specific-gravity determinations, is 1,800 tons per acre-foot (Averitt and others, 1953, p. 7). This weight was used in calculating the reserves of coal in Beaver County.

In order to provide as much information as possible on the distribution of reserves, estimates prepared by the U.S. Geological Survey are divided into three categories according to the thickness of the coal. These categories are termed "thin," "intermediate," and "thick." "Thin" coal is 14-28 inches thick; "intermediate" coal is $28-42$ inches thick; and "thick" coal is more than 42 inches thick. These thickness categories are based primarily on the following mining practices in current usage by the mining industry in the United States: The minimum thickness of coal mined by hand is approximately 14 inches; the minimum thickness generally considered for machine mining and hand loading is 28 inches; and the minimum thickness required for completely mechanized mining is approximately 42 inches. Results of this study show that in Beaver County, 74 percent of the total re- 
serves is in "thin" coal beds, 23 percent is in "intermediate" coal beds and 3 percent is in "thick" coal beds (table 1 ).

In the procedure for calculating coal reserves that is used by the U.S. Geological Survey, the coal is also separated into categories based on the depth of the coal or amount of overburden. The thicknesses of overburden generally considered are: less than 1,000 feet, 1,000-2,000 feet, and 2,000-3,000 feet. Coals at depths of more than 3,000 feet are not considered to be recoverable under present economic conditions. None of the coals for which reserves were calculated in Beavèr County are more than 1,000 feet below the surface. Actually,

\section{TARLE 2.-Classification of coals by rank}

[From American Society for Testing Materials (1939, p. 2)]

Explanation: FC, fixed carbon; VM, volatile matter; Btu, British thermal units. This classification does not include a few coals which have unusual physical and chemical properties and which come within the limits of fixed carbon or Btu of the high-volatile bituminous and subbituminous ranks. All these coals either contain less than 48 percent dry, mineral-matter-free fixed carbon or have more than 15,500 moist, mineral-matterfree Btu.

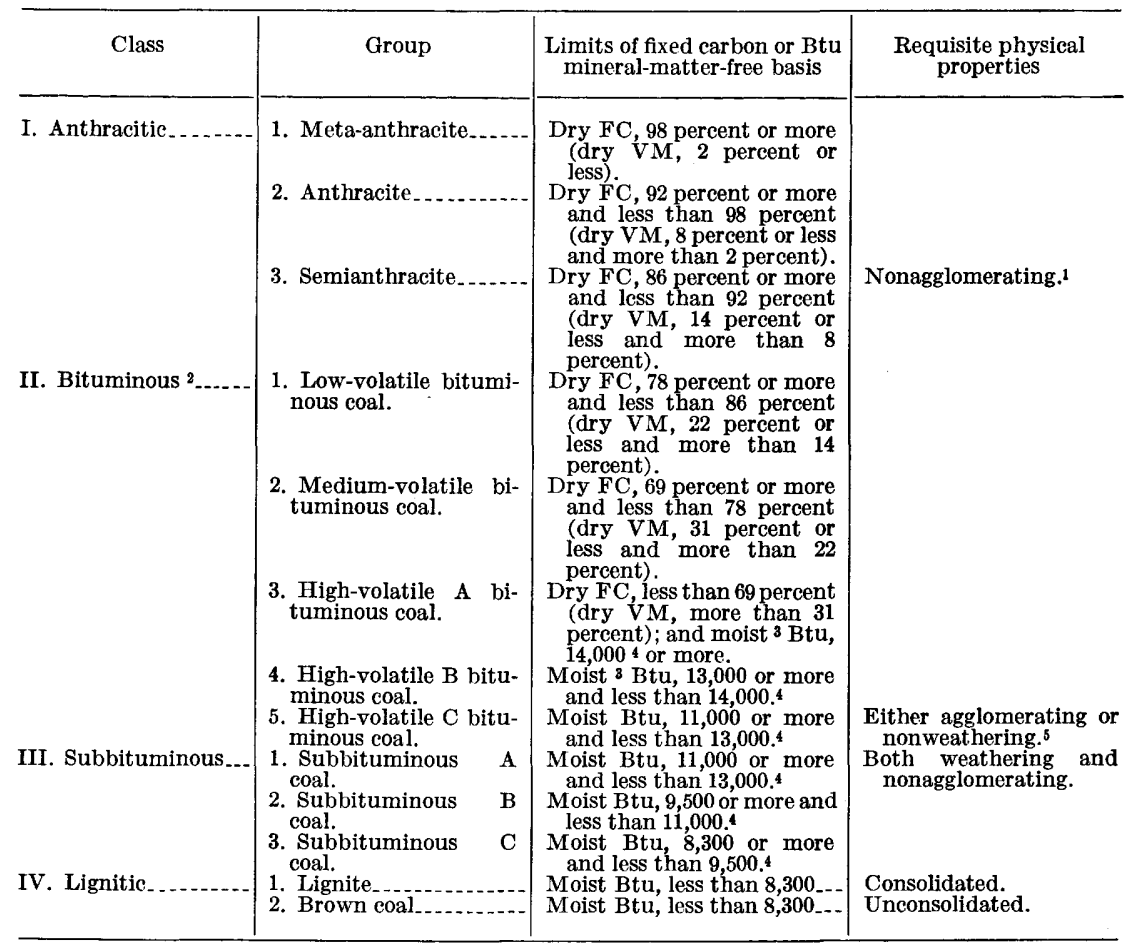

1 If agglomerating, classify in low-volatile group of the bituminous class.

2 It is recognized that there may be noncaking varieties in each group of the bituminous class.

3 Moist Btu refers to coal containing its natural bed moisture but not including visible water on the surface of the coal.

4 Coals having 69 percent or more fixed carbon on the dry, mineral-matter-free basis shall be classified according to fixed carbon, regardless of Btu.

5 There are three varieties of coal in the high-volatile $\mathrm{C}$ bitumi nous coal group, namely, variety 1 , agglomerating and nonweathering; variety 2, agglomerating and we athering; variety 3, nonagglomerating and nonweathering. 
each bed can be mined by stripping methods in many places. Because of the relatively large quantity of strippable coal in Beaver County, the reserves have been further classified so as to show the amount of coal beneath 60 feet or less of overburden (table 3). Approximately 7 percent of the coal in the county is estimated to be within this category. Table 3 shows the distribution of strippable coal by bed and by quadrangle. The remaining 93 percent of the coal in the county is under $60-1,000$ feet of overburden, and the reserves in this category are similarly listed in table 4.

\section{CLASSIFICATION INTO MEASURED, INDICATED, AND INFERRED RESERVES}

According to the abundance and reliability of data upon which the estimates are based, estimates of coal reserves prepared by the U.S. Geological Survey are divided into three categories: Measured, indicated, and inferred.

Measured reserves are those for which tonnage is computed from the thickness of the coal beds revealed in outcrops, prospect openings, mine workings, and drill holes. The points of observation are so closely spaced and thickness and extent of the coal so well defined that computed tonnage is considered to be accurate within 20 percent of the true tonnage. Although the spacing of points of observation necessary to demonstrate continuity of coal varies in different regions according to the character of the coal beds and the geologic structure, points of observation are generally about half a mile apart.

Indicated reserves are those for which tonnage is computed partly from specific measurements and partly from assumption based on available data and on geologic evidence. In general, the points of coal measurement are about 1 mile apart, but they may be as much as $11 / 2$ miles apart in beds of known geologic continuity.

Inferred reserves are those for which quantitative estimates are based on a broad knowledge of the character of the bed or region and for which there are few, if any, measurements of the coal. The estimates are based on an assumed continuity for which there is good geologic evidence. In general, inferred reserves lie more than 2 miles from points of observed thickness.

\section{CLASSIFICATION INTO ORIGINAL, REMAINING, AND RECOVERABLE RESERVES}

Coal reserves are further classified as original, remaining, and recoverable. Original reserves are the reserves that were in the ground before mining began.

Remaining reserves are the reserves in the ground as of the date of appraisal. In many areas, mine data are sufficient to make it possible 
to plot on the work maps the extent of both the coal bed and the minedout areas and to measure separately the remaining coal and the mined-out areas. In Beaver County, however, where mine data are insufficient for accurate plotting of mined-out areas, the figure for remaining reserves was obtained by subtracting recorded production plus an allowance for mining losses from original reserves. Furthermore, reported production of coal in Beaver County is so small in comparison to estimated original reserves that original and remaining reserves are considered to be equal in this report. Adherence to this concept explains the absence of production tonnages in tables 1,3 , and 4.

Recoverable reserves are reserves in the ground, as of the date of appraisal, that can be produced in the future. The amount of these reserves is obtained by subtracting estimated future losses in mining from remaining reserves. Recoverability of coal from any area is mainly an engineering problem involving such variable factors as geologic structure, thickness, and quality. Consequently, the percentage of coal that can be recovered in mining varies from one area to another. Reported coal production in Beaver County from 1881 to 1955 is 15 million tons (Maize and Struble, 1955). Using a 50-percent recoverability factor for underground mining, a factor based on a nationwide arerage (Averitt and others, 1953, p. 12), and an assumed 80-percent recoverability factor for strip mining, 28 million tons of coal is estimated to have been mined or lost in mining since 1881 . Assuming that future recoverability will be comparable to that in the past, recoverable reserves of coal in Beaver County as of January 1, 1956, are estimated to be 1,286 million tons. Technological advances resulting in greater efficiency in mining will doubtlessly increase the percentage of recoverability.

\section{METHODS OF RECORDING DATA AND MAKING CALCULATIONS}

The locations of observed outcrops of coal beds were plotted on topographic maps of Beaver County, and the lateral extent of the coal was determined from the outcrop, drill-hole, and mine data. All measurements of coal thickness from outcrops, drill holes, and mines were also plotted on the map, and thickness lines were then drawn on the basis of the plotted information, dividing the coal into three categories: 14-28 inches, 28-42 inches, and more than 42 inches. Other lines were drawn, dividing the bed into measured, indicated, and inferred categories on the basis of the spacing of the data.

Within each of the thickness categories shown on plate 5 , a weighted a verage thickness for the coal was obtained by using all measurements from outcrops, mines, and drill holes. The figures used are the measured thicknesses of the coal bed minus partings, except where the 
TaBLe 3.-Estimated original bituminous coal reserves, in millions of short tons, in Beaver County, Pa., under less than 60 feet of overburden

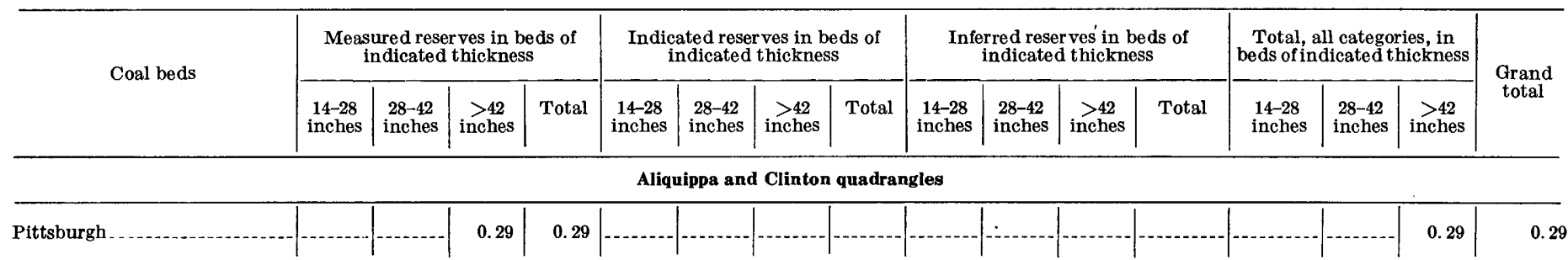

Ambridge and Baden quadrangles

\begin{tabular}{|c|c|c|c|c|c|c|c|c|c|c|c|c|c|c|c|c|}
\hline $\begin{array}{l}\text { Brush Creek } \\
\text { Upper Freeport } \\
\text { Lower Freeport } \\
\text { Lower Kittanning }\end{array}$ & $\begin{array}{r}0.22 \\
.04 \\
\hdashline .09\end{array}$ & $\begin{array}{c}0.55 \\
.07 \\
-0 .-1\end{array}$ & 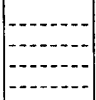 & $\begin{array}{r}0.77 \\
.04 \\
.07 \\
.09\end{array}$ & \begin{tabular}{r|}
0.24 \\
.32 \\
-.08
\end{tabular} & $\begin{array}{r}0.66 \\
.36 \\
.04\end{array}$ & 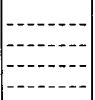 & $\begin{array}{r}0.90 \\
.68 \\
.04 \\
.08\end{array}$ & 0.05 & 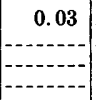 & & 0.08 & $\begin{array}{r}0.51 \\
.36 \\
.17\end{array}$ & $\begin{array}{r}1.24 \\
.36 \\
.11 \\
--.\end{array}$ & 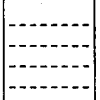 & $\begin{array}{r}1.75 \\
.72 \\
.11 \\
.17\end{array}$ \\
\hline Total & .35 & .62 & -...-... & .97 & .64 & 1.06 & & 1.70 & .05 & .03 & $\ldots$ & .08 & 1.04 & 1.71 & & 2.75 \\
\hline
\end{tabular}

Beaver quadrangle

\begin{tabular}{|c|c|c|c|c|c|c|c|c|c|c|c|c|c|c|c|c|}
\hline $\begin{array}{l}\text { Upper Freeport } \\
\text { Lower Kittanning }\end{array}$ & $\begin{array}{r}0.08 \\
.19\end{array}$ & $\begin{array}{r}0.43 \\
.13\end{array}$ & $\mid-1-1-1$ & $\begin{array}{r}0.51 \\
.32\end{array}$ & -. & & 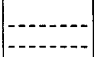 & & -- & - & $\mid \ldots$ & $\mid-1-1-1$, & $\begin{array}{r}0.08 \\
.19\end{array}$ & $\begin{array}{r}0.43 \\
.13\end{array}$ & & $\begin{array}{r}0.51 \\
.32\end{array}$ \\
\hline Total & 27 & .56 & $\ldots$ & .83 & & & & & & & & & .27 & .56 & & .83 \\
\hline
\end{tabular}

\section{Burgettstown, Hookstown, Steubenville NE, and Wellsville SE quadrangles}

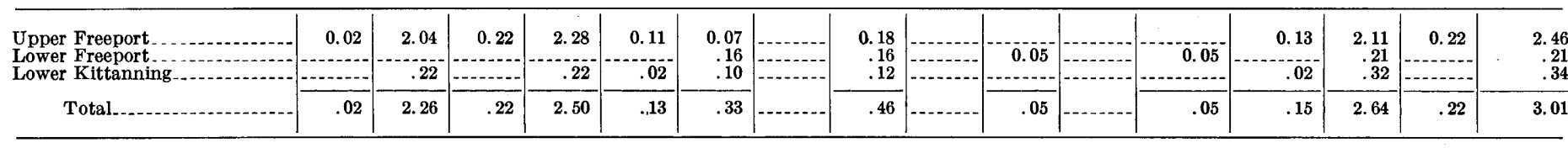




\section{Columbiana SE and New Castle SW quadrangles}

\begin{tabular}{|c|c|c|c|c|c|c|c|c|c|c|c|c|c|c|c|c|}
\hline $\begin{array}{l}\text { Mahoning } \\
\text { Upper Freeport } \\
\text { Lower Freeport } \\
\text { Middle Kittanning } \\
\text { Lower Kittanning }\end{array}$ & $\begin{array}{l}1.80 \\
.30 \\
2.04 \\
1.27 \\
2.76\end{array}$ & $\begin{array}{r}4.03 \\
8.78 \\
3.10 \\
.96 \\
1.49\end{array}$ & \begin{tabular}{r|}
0.98 \\
11.10 \\
\hdashline-10 \\
\hdashline-10 \\
\end{tabular} & $\begin{array}{r}6.81 \\
20.18 \\
5.14 \\
2.23 \\
4.25\end{array}$ & \begin{tabular}{r|}
0.75 \\
-3.36 \\
.26 \\
3.15 \\
\end{tabular} & $\begin{array}{r}0.20 \\
11.36 \\
6.62 \\
.47 \\
1.22\end{array}$ & 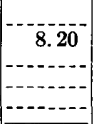 & $\begin{array}{r}0.95 \\
19.56 \\
9.98 \\
.73 \\
4.37\end{array}$ & 0.40 & \begin{tabular}{c}
0.04 \\
\hdashline-1 \\
-0
\end{tabular} & $\mid$\begin{tabular}{l}
$-\cdots-\cdot-$ \\
\hdashline$-\cdots$
\end{tabular} & \begin{tabular}{r}
0.04 \\
.40 \\
\hdashline \\
\end{tabular} & $\begin{array}{l}2.55 \\
.30 \\
5.80 \\
1.53 \\
5.91\end{array}$ & $\begin{array}{r}4.23 \\
20.18 \\
9.72 \\
1.43 \\
2.71\end{array}$ & \begin{tabular}{|r|}
$0: 98$ \\
19.30 \\
-0 \\
$-0 .-$ \\
\end{tabular} & $\begin{array}{r}7.76 \\
39.78 \\
15.52 \\
2.96 \\
8.62\end{array}$ \\
\hline Total.- & 8.17 & 18. 36 & 12.08 & 38.61 & 7.52 & 19.87 & 8.20 & 35.59 & .40 & .04 & -- & .44 & 16.09 & 38.27 & 20.28 & 74. 64 \\
\hline
\end{tabular}

Midland and Wellsville NE quadrangles

\begin{tabular}{|c|c|c|c|c|c|c|c|c|c|c|c|c|c|c|c|c|}
\hline $\begin{array}{l}\text { Upper Freeport } \\
\text { Lower Freeport } \\
\text { Lower Kittanning }\end{array}$ & 0.03 & $\begin{array}{r}6.55 \\
.30 \\
.29\end{array}$ & $\begin{array}{r}5.80 \\
-2-\end{array}$ & $\begin{array}{r}12.35 \\
.30 \\
.32\end{array}$ & $\begin{array}{c}0.66 \\
.18\end{array}$ & $\begin{array}{r}1.60 \\
1.12 \\
.35\end{array}$ & 0.50 & $\begin{array}{r}2.76 \\
1.12 \\
.53\end{array}$ & & $\begin{array}{l}0.02 \\
\end{array}$ & & 0.02 & 0.66 & $\begin{array}{r}8.15 \\
1.44 \\
.64\end{array}$ & 6.30 & $\begin{array}{r}15.11 \\
1.44 \\
.85\end{array}$ \\
\hline - & .03 & 7.14 & 5.80 & 12.97 & .84 & 3.07 & .50 & 4.41 & & .02 & & .02 & .87 & 10.23 & 6.30 & 17.40 \\
\hline
\end{tabular}

\section{New Castle SE quadrangle}

\begin{tabular}{|c|c|c|c|c|c|c|c|c|c|c|c|c|c|c|c|c|}
\hline $\begin{array}{l}\text { Upper Freeport } \\
\text { Middle Kittanning } \\
\text { Lower Kittanning }\end{array}$ & $\begin{array}{l}1.71 \\
1.40\end{array}$ & $\begin{array}{l}6.14 \\
2.59 \\
1.94\end{array}$ & $\begin{array}{r}3.69 \\
\hdashline-1- \\
\hdashline-19\end{array}$ & $\begin{array}{l}9.83 \\
4.30 \\
3.34\end{array}$ & $\begin{array}{l}0.66 \\
1.56\end{array}$ & $\begin{array}{l}6.53 \\
.42\end{array}$ & 10.13 & $\begin{array}{r}16.66 \\
.66 \\
1.98\end{array}$ & 0.11 & & & 0.11 & $\begin{array}{l}2.37 \\
3.07\end{array}$ & $\begin{array}{r}12.67 \\
2.59 \\
2.36\end{array}$ & 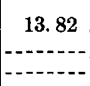 & $\begin{array}{r}26.49 \\
4.96 \\
5.43\end{array}$ \\
\hline Total & 3.11 & 10.67 & 3.69 & 17.47 & 2.22 & 6.95 & 10.13 & 19.30 & .11 & . & & .11 & 5.44 & 17.62 & 13.82 & 36.88 \\
\hline \multicolumn{17}{|c|}{ Zelienople SW quadrangle } \\
\hline $\begin{array}{l}\text { Upper Freeport } \\
\text { Middle Kittanning } \\
\text { Lower Kittanning }\end{array}$ & $\begin{array}{l}0.12 \\
.36 \\
3.08\end{array}$ & $\begin{array}{l}0.44 \\
1.24 \\
3.38\end{array}$ & -..-- & $\begin{array}{l}0.56 \\
1.60 \\
6.46\end{array}$ & $\begin{array}{l}0.61 \\
1.01\end{array}$ & $\begin{array}{r}0.61 \\
.22 \\
.15\end{array}$ & (n) & $\begin{array}{l}0.61 \\
.83 \\
1.16\end{array}$ & & & & & $\begin{array}{r}0.12 \\
.97 \\
4.09\end{array}$ & $\begin{array}{l}1.05 \\
1.46 \\
\text { 3. } 53\end{array}$ & & $\begin{array}{l}1.17 \\
2.43 \\
7.62\end{array}$ \\
\hline Total... & 3.56 & 5.06 & & 8.62 & 1.62 & 0.98 & $\ldots$ & 2.60 & ..... & & & $\ldots$ & 5.18 & 6.04 & $\ldots$ & 11.22 \\
\hline Total, all quadrangles.... & 15. 51 & 44.67 & 22.08 & 82.26 & 12.97 & 32.26 & 18.83 & 64.06 & 0.56 & 0.14 & $\ldots$ & 0.70 & 29.04 & 77.07 & 40.91 & 147.02 \\
\hline
\end{tabular}


TaBLE 4.-Estimated original bituminous coal reserves, in millions of short toms; in Beaver County, Pa., under 60-1,000 feet of overburden

\begin{tabular}{|c|c|c|c|c|c|c|c|c|c|c|c|c|c|c|c|c|}
\hline \multirow{2}{*}{ Coal bed } & \multicolumn{4}{|c|}{$\begin{array}{l}\text { Measured reserves in beds of } \\
\text { indicated thickness }\end{array}$} & \multicolumn{4}{|c|}{$\begin{array}{l}\text { Indicated reserves in beds of } \\
\text { indicated thickness }\end{array}$} & \multicolumn{4}{|c|}{$\begin{array}{l}\text { Inferred reserves in beds of } \\
\text { indicated thickness }\end{array}$} & \multicolumn{3}{|c|}{$\begin{array}{c}\text { Total, all categories, in } \\
\text { beds of indicated thickness }\end{array}$} & \multirow{2}{*}{$\begin{array}{c}\text { Grand } \\
\text { total }\end{array}$} \\
\hline & $\begin{array}{l}\text { 14-28 } \\
\text { inches }\end{array}$ & $\begin{array}{l}28-42 \\
\text { inches }\end{array}$ & $\underset{\text { inches }}{>42}$ & Total & $\begin{array}{l}14-28 \\
\text { inches }\end{array}$ & $\begin{array}{l}28-42 \\
\text { inches }\end{array}$ & $\underset{\text { inches }}{>42}$ & Total & $\begin{array}{l}14-28 \\
\text { inches }\end{array}$ & $\begin{array}{l}28-42 \\
\text { inches }\end{array}$ & $\underset{\text { inches }}{>42}$ & Total & $\begin{array}{l}14-28 \\
\text { inches }\end{array}$ & $\begin{array}{l}28-42 \\
\text { inches }\end{array}$ & $\underset{\text { inches }}{>42}$ & \\
\hline \multicolumn{17}{|c|}{ Aliquippa and Clinton quadrangles } \\
\hline $\begin{array}{l}\text { Upper Freeport } \\
\text { Lower Freeport } \\
\text { Middle Kittanning } \\
\text { Lower Kittanning }\end{array}$ & $\begin{array}{r}3.45 \\
.11 \\
.24 \\
3.81\end{array}$ & 2.81 & & $\begin{array}{r}6.26 \\
.11 \\
.24 \\
3.81\end{array}$ & $\begin{array}{r}18.36 \\
8.54 \\
5.65 \\
7.22\end{array}$ & $\begin{array}{r}3.16 \\
\hdashline-1 \\
\hdashline-1\end{array}$ & $--\cdot$ & $\begin{array}{r}21.52 \\
8.54 \\
5.65 \\
7.22\end{array}$ & $\begin{array}{r}5.98 \\
11.45 \\
54.83 \\
77.51\end{array}$ & & & $\begin{array}{r}5.98 \\
11.45 \\
54.83 \\
77.51\end{array}$ & $\begin{array}{l}27.79 \\
20.10 \\
60.72 \\
88.54\end{array}$ & $\begin{array}{r}5.97 \\
\hdashline-1-1 \\
\hdashline-1-1\end{array}$ & & $\begin{array}{l}33.76 \\
20.10 \\
60.72 \\
88.54\end{array}$ \\
\hline Total... & 7.61 & 2.81 & & 10.42 & 39.77 & 3.16 & & 42.93 & 149.77 & & & 149.77 & 197.15 & 5.97 & & 203.12 \\
\hline \multicolumn{17}{|c|}{ Ambridge and Baden quadrangles } \\
\hline $\begin{array}{l}\text { Brush Creek } \\
\text { Upper Freeport } \\
\text { Lower Freeport } \\
\text { Middle Kittanning } \\
\text { Lower Kittanning }\end{array}$ & $\begin{array}{l}0.42 \\
4.11 \\
1.32 \\
1.87 \\
1.62\end{array}$ & $\begin{array}{r}0.46 \\
.42 \\
.86 \\
.18\end{array}$ & $\begin{array}{l}-- \\
-- \\
-- \\
--\end{array}$ & $\begin{array}{l}0.88 \\
4.53 \\
2.18 \\
1.87 \\
1.80\end{array}$ & $\begin{array}{r}2.36 \\
9.13 \\
19.96 \\
18.94 \\
28.08\end{array}$ & $\begin{array}{r}2.52 \\
.36 \\
1.48 \\
.25\end{array}$ & |- & $\begin{array}{r}4.88 \\
9.49 \\
21.44 \\
18.94 \\
28.33\end{array}$ & $\begin{array}{r}7.67 \\
28.71 \\
36.20 \\
61.26 \\
66.02\end{array}$ & 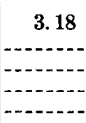 & & $\begin{array}{l}10.85 \\
28.71 \\
36.20 \\
61.26 \\
66.02\end{array}$ & $\begin{array}{l}10.45 \\
41.95 \\
57.48 \\
82.07 \\
95.72\end{array}$ & $\begin{array}{r}6.16 \\
.78 \\
2.34 \\
.43\end{array}$ & & $\begin{array}{l}16.61 \\
42.73 \\
59.82 \\
82.07 \\
96.15\end{array}$ \\
\hline Total & 9.34 & 1.92 & & 11.26 & 78.47 & 4.61 & & 83.08 & 199.86 & 3.18 & & 203.04 & 287.67 & 9.71 & & 297.38 \\
\hline \multicolumn{17}{|c|}{ Beaver quadrangle } \\
\hline $\begin{array}{l}\text { Upper Freeport } \\
\text { Lower Freeport } \\
\text { Middle Kittanning } \\
\text { Lower Kittanning }\end{array}$ & $\begin{array}{r}20.44 \\
1.74 \\
2.97 \\
20.08\end{array}$ & \begin{tabular}{l}
4.65 \\
\hdashline 7.60
\end{tabular} & & $\begin{array}{r}25.09 \\
1.74 \\
2.97 \\
27.68\end{array}$ & $\begin{array}{l}27.43 \\
17.39 \\
14.98 \\
34.46\end{array}$ & $\begin{array}{r}4.47 \\
\hdashline 2.74\end{array}$ & 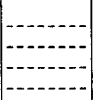 & $\begin{array}{l}31.90 \\
17.39 \\
14.98 \\
37.20\end{array}$ & $\begin{array}{r}0.10 \\
7.84 \\
21.07 \\
18.83\end{array}$ & & & $\begin{array}{r}0.10 \\
7.84 \\
21.07 \\
18.83\end{array}$ & $\begin{array}{l}47.97 \\
26.97 \\
39.02 \\
73.37\end{array}$ & $\begin{array}{c}9.12 \\
10.34\end{array}$ & & $\begin{array}{l}57.09 \\
26.97 \\
39.02 \\
83.71\end{array}$ \\
\hline Total & 45.23 & 12.25 & - & 57.48 & 94.26 & 7.21 & $-\ldots$ & 101.47 & 47.84 & & & 47.84 & 187.33 & 19.46 & - & 206.79 \\
\hline
\end{tabular}


Burgettstown, Hookstown, Steubenville NE, and Wellsville SE quadrangles

\begin{tabular}{|c|c|c|c|c|c|c|c|c|c|c|c|c|c|c|c|c|}
\hline $\begin{array}{l}\text { Upper Freeport } \\
\text { Lower Freeport } \\
\text { Middle Kittanning } \\
\text { Lower Kittanning }\end{array}$ & $\begin{array}{r}25.34 \\
.71 \\
.42 \\
4.64\end{array}$ & $\begin{array}{r}10.88 \\
.24 \\
\hdashline 1.74\end{array}$ & 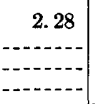 & $\begin{array}{r}38.50 \\
.95 \\
.42 \\
6.38\end{array}$ & $\begin{array}{r}6.88 \\
6.18 \\
15.18 \\
27.66\end{array}$ & $\begin{array}{c}36.39 \\
6.76 \\
1.25\end{array}$ & 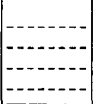 & $\begin{array}{l}43.27 \\
12.94 \\
15.18 \\
28.91\end{array}$ & $\begin{array}{r}11.61 \\
80.24 \\
89.86 \\
104.84 \\
\end{array}$ & 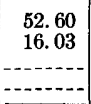 & & $\begin{array}{r}64.21 \\
96.27 \\
89.86 \\
104.84 \\
\end{array}$ & $\begin{array}{r}43.83 \\
87.13 \\
105.46 \\
137.14\end{array}$ & $\begin{array}{r}99.87 \\
23.03 \\
2.99\end{array}$ & $\begin{array}{r}2.28 \\
\hdashline-2- \\
\hdashline-10\end{array}$ & $\begin{array}{l}145.98 \\
110.16 \\
105.46 \\
140.13\end{array}$ \\
\hline Total. & 31.11 & 12.86 & 2.28 & 46.25 & 55.90 & 44.40 & $\mid-----$ & 100.30 & 286.55 & 68.63 & & 355.18 & 373.56 & 125.89 & 2.28 & 501.73 \\
\hline \multicolumn{17}{|c|}{ Columbiana $S E$ and New Castle $S W$ quadrangles } \\
\hline $\begin{array}{l}\text { Mahoning } \\
\text { Upper Freeport } \\
\text { Lower Freeport } \\
\text { Upper Kittanning-- } \\
\text { Middle Kittanning-- } \\
\text { Lower Kittanning - }\end{array}$ & $\begin{array}{r}1.09 \\
8.81 \\
12.41 \\
12.82\end{array}$ & $\begin{array}{r}4.60 \\
11.14 \\
5.39 \\
2.43 \\
5.89\end{array}$ & $\begin{array}{r}0.06 \\
6.68 \\
\hdashline 1.21 \\
\hdashline \\
\hdashline-0\end{array}$ & $\begin{array}{r}4.66 \\
18.91 \\
14.20 \\
1.21 \\
14.84 \\
18.71\end{array}$ & $\begin{array}{r}0.07 \\
.94 \\
41.73 \\
46.53 \\
53.81\end{array}$ & $\begin{array}{r}0.60 \\
11.45 \\
15.81 \\
4.85 \\
8.08\end{array}$ & 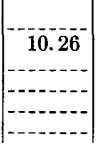 & $\begin{array}{r}0.67 \\
22.65 \\
57.54 \\
-51.38 \\
61.89\end{array}$ & $\begin{array}{r}8.81 \\
8.95 \\
22.17\end{array}$ & 0.25 & & $\begin{array}{r}0.25 \\
8.81 \\
8.95 \\
25.62\end{array}$ & $\begin{array}{r}0.07 \\
2.03 \\
59.35 \\
67.89 \\
88.80\end{array}$ & $\begin{array}{r}5.20 \\
22.84 \\
21.20 \\
-7.28 \\
17.42\end{array}$ & $\begin{array}{c}0.06 \\
16.94 \\
1.21 \\
-0\end{array}$ & $\begin{array}{r}5.33 \\
41.81 \\
80.55 \\
1.21 \\
75.17 \\
106.22\end{array}$ \\
\hline Total. & 35.13 & 29.45 & 7.95 & 72.53 & 143.08 & 40.79 & 10.26 & 194.13 & 39.93 & 3.70 & & 43.63 & 218.14 & 73.94 & 18.21 & 310.29 \\
\hline \multicolumn{17}{|c|}{ Midland and Wellsville NE quadrangles } \\
\hline $\begin{array}{l}\text { Upper Freeport } \\
\text { Lower Freeport } . . . \\
\text { Middle Kittanning- } \\
\text { Lower Kittanning.- }\end{array}$ & $\begin{array}{r}11.23 \\
1.47 \\
7.07 \\
3.74\end{array}$ & $\begin{array}{r}23.84 \\
1.42 \\
8.10\end{array}$ & $\begin{array}{c}7.15 \\
.32\end{array}$ & $\begin{array}{r}42.22 \\
2.89 \\
7.07 \\
12.16\end{array}$ & $\begin{array}{l}18.38 \\
24.29 \\
88.41 \\
32.02\end{array}$ & $\begin{array}{r}51.00 \\
16.77 \\
32.56\end{array}$ & $\mid$\begin{tabular}{r}
7.59 \\
\hdashline-10 \\
-
\end{tabular} & $\begin{array}{l}76.97 \\
41.06 \\
88.41 \\
64.58\end{array}$ & $\begin{array}{r}3.56 \\
38.79 \\
36.06 \\
49.06\end{array}$ & $\begin{array}{r}5.94 \\
10.13 \\
36.01\end{array}$ & & $\begin{array}{r}9.50 \\
48.92 \\
36.06 \\
85.07\end{array}$ & $\begin{array}{r}33.17 \\
64.55 \\
131.54 \\
84.82\end{array}$ & $\begin{array}{r}80.78 \\
28.32 \\
76.67\end{array}$ & $\begin{array}{c}14.74 \\
.32\end{array}$ & $\begin{array}{r}128.69 \\
92.87 \\
131.54 \\
161.81\end{array}$ \\
\hline Total & 23.51 & 33.36 & 7.47 & 64.34 & 163.10 & 100.33 & 7.59 & 271.02 & 127.47 & 52.08 & & 179.55 & 314.08 & 185.77 & 15.06 & 514.91 \\
\hline \multicolumn{17}{|c|}{ New Castle SE quadrangle } \\
\hline $\begin{array}{l}\text { Upper Freeport. } \\
\text { Lower Freeport } \\
\text { Upper Kittanning }\end{array}$ & $\begin{array}{r}3.45 \\
-\end{array}$ & 5.03 & 3.30 & 11.78 & 9.60 & 8.23 & 8.90 & 26. 73 & 0.25 & & & 0.25 & 13. 30 & 13.26 & 12.20 & 38.76 \\
\hline $\begin{array}{l}\text { Middle Kittanning } \\
\text { Lower Kittanning. }\end{array}$ & $\begin{array}{l}11.95 \\
12.54\end{array}$ & $\begin{array}{r}11.41 \\
4.91\end{array}$ & $\mid$ & $\begin{array}{l}23.36 \\
17.45\end{array}$ & $\begin{array}{l}21.75 \\
38.38\end{array}$ & $\begin{array}{r}14.79 \\
8.04\end{array}$ & 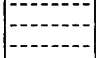 & $\begin{array}{l}36.54 \\
46.42\end{array}$ & $\begin{array}{l}3.52 \\
6.91\end{array}$ & & & 3. 92 & $\begin{array}{l}37.22 \\
57.83\end{array}$ & $\begin{array}{l}26.20 \\
12.95\end{array}$ & 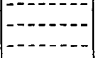 & $\begin{array}{l}63.42 \\
70.78\end{array}$ \\
\hline Total. & 27.94 & 21.35 & 3.30 & 52.59 & 69. 73 & 31.06 & 8.90 & 109.69 & 10.68 & & & 10.68 & 108.35 & 52.41 & 12.20 & 172.96 \\
\hline
\end{tabular}


TABLE 4.-Estimated original bituminous coal reserves, in millions of short tons, in Beaver County, Pa., under 60-1,000 feet of overburden-Continued

\begin{tabular}{|c|c|c|c|c|c|c|c|c|c|c|c|c|c|c|c|c|}
\hline \multirow{2}{*}{ Coal bed } & \multicolumn{4}{|c|}{$\begin{array}{l}\text { Measured reserves in beds of } \\
\text { indicated thickness }\end{array}$} & \multicolumn{4}{|c|}{$\begin{array}{l}\text { Indicated reserves in beds of } \\
\text { indicated thickness }\end{array}$} & \multicolumn{4}{|c|}{$\begin{array}{l}\text { Inferred reserves in beds of } \\
\text { indicated thickness }\end{array}$} & \multicolumn{3}{|c|}{$\begin{array}{l}\text { Total, all categories, in } \\
\text { beds of indicated thickness }\end{array}$} & \multirow{2}{*}{$\begin{array}{l}\text { Grand } \\
\text { total }\end{array}$} \\
\hline & $\begin{array}{l}14-28 \\
\text { inches }\end{array}$ & $\begin{array}{l}28-42 \\
\text { inches }\end{array}$ & $\underset{\text { inches }}{>42}$ & Total & $\begin{array}{c}14-28 \\
\text { inches }\end{array}$ & $\begin{array}{c}28-42 \\
\text { inches }\end{array}$ & $\underset{\text { inches }}{>42}$ & Total & $\begin{array}{c}14-28 \\
\text { inches }\end{array}$ & $\begin{array}{c}28-42 \\
\text { inches }\end{array}$ & $\underset{\text { inches }}{>42}$ & Total & $\begin{array}{l}14-28 \\
\text { inches }\end{array}$ & $\begin{array}{l}28-42 \\
\text { inches }\end{array}$ & $\underset{\text { inches }}{>42}$ & \\
\hline \multicolumn{17}{|c|}{ Zelienople SE quadrangle } \\
\hline $\begin{array}{l}\text { Upper Freeport } \\
\text { Lower Freeport } \\
\text { Middle Kittanning } \\
\text { Lower Kittanning }\end{array}$ & $\begin{array}{l}1.82 \\
.13 \\
8.03 \\
4.27 \\
\end{array}$ & $\begin{array}{r}0.38 \\
4.76 \\
.99 \\
\end{array}$ & 1.10 & $\begin{array}{r}2.20 \\
.13 \\
13.89 \\
5.26\end{array}$ & $\begin{array}{r}10.02 \\
2.20 \\
23.85 \\
38.89\end{array}$ & $\begin{array}{r}3.80 \\
-16.59 \\
\quad .10\end{array}$ & $(-\cdots+\cdots$ & $\begin{array}{r}13.82 \\
2.20 \\
40.44 \\
38.99\end{array}$ & $\begin{array}{r}4.01 \\
10.88 \\
7.43 \\
22.03\end{array}$ & $\begin{array}{r}0.29 \\
.76\end{array}$ & & $\begin{array}{r}4.30 \\
10.88 \\
8.19 \\
22.03\end{array}$ & $\begin{array}{l}15.85 \\
13.21 \\
39.31 \\
65.19\end{array}$ & $\begin{array}{r}4.47 \\
22.11 \\
1.09\end{array}$ & 1.10 & $\begin{array}{l}20.32 \\
13.21 \\
62.52 \\
66.28 \\
\end{array}$ \\
\hline Total... & 14.25 & 6.13 & 1.10 & 21.48 & 74.96 & 20.49 & - nn & $\overline{95.45}$ & 44.35 & 1.05 & & 45.40 & 133.56 & 27.67 & 1.10 & 162.33 \\
\hline Total, all quadrangles & 194.12 & 120.13 & 22.10 & 336.35 & 719.27 & 252.05 & 26. 75 & 998.07 & 906.45 & 128.64 & & $1,035.09$ & $1,819.84$ & 500.82 & 48.85 & 2.369. 51 \\
\hline
\end{tabular}


partings exceed half the total thickness of the coal bed. Where more than one-half of the coal bed consists of partings, the coal is not considered to be commercially minable and, therefore, is excluded from the estimate.

The areas outlined on the map were measured with a planimeter to obtain the acreage underlain by coal in the different categories of thickness and reliability. Tonnage was calculated by multiplying the number of acres by a weighted average thickness of the coal to the nearest tenth of a foot by 1,800 (weight of bituminous coal in tons per acre-foot). Tonnages were tabulated by quadrangle and by beds, and placed in categories according to thickness of coal and reliability of information (tables 1, 2, and 3). For convenience in arranging the table, tonnages are listed in millions of short tons.

\section{PREVIOUS ESTIMATES OF THE COAL RESERVES IN BEAVER COUNTY}

The only previous estimates of the coal reserves in Beaver County were made by Sisler (Reese and Sisler, 1928, pt. 3, p. 26-32). He estimated that the original reserves of the county were 1,262 million tons and that the recoverable reserves were 651 million tons. His estimates, which are tabulated by bed and by township, included reserves for the Pittsburgh, Upper Freeport, Lower Freeport, Middle Kittanning, Lower Kittanning, and Brookville coal beds. Although the methods of plotting data and calculating tonnages employed by Sisler were similar to those used for this report, his estimate is smaller than the present estimate for several reasons: he did not include estimates for the Mahoning and Brush Creek beds; he excluded all coal less than 18 inches thick; and he assumed a weight of only 90,000 tons per inch of bed per square mile of area, which is low for coal in the ground. The assumed weight of 1,800 tons per acre-foot used in this report is equivalent to 96,000 tons per inch of bed per square mile of area.

\section{RANK AND QUALITY OF COAL}

Most of the coal in Beaver County is of high-volatile A bituminous rank. Rank varies slightly within each bed from one place to another and also from one bed to another in the same general area. No trend in increase or decrease of rank as a function of depth of burial can be depicted. All coals in Beaver County for which reserves were calculated are relatively low in both ash and sulfur. Individual analyses by bed are listed in table 5 . 
TABLE 5.-Analyses of coal samples from Beaver County, Pa., and adjacent areas

[Condition of sample: A, as received; B, moisture-free; C, moisture- and ash-free. Calorific heating value computed from Btu value]

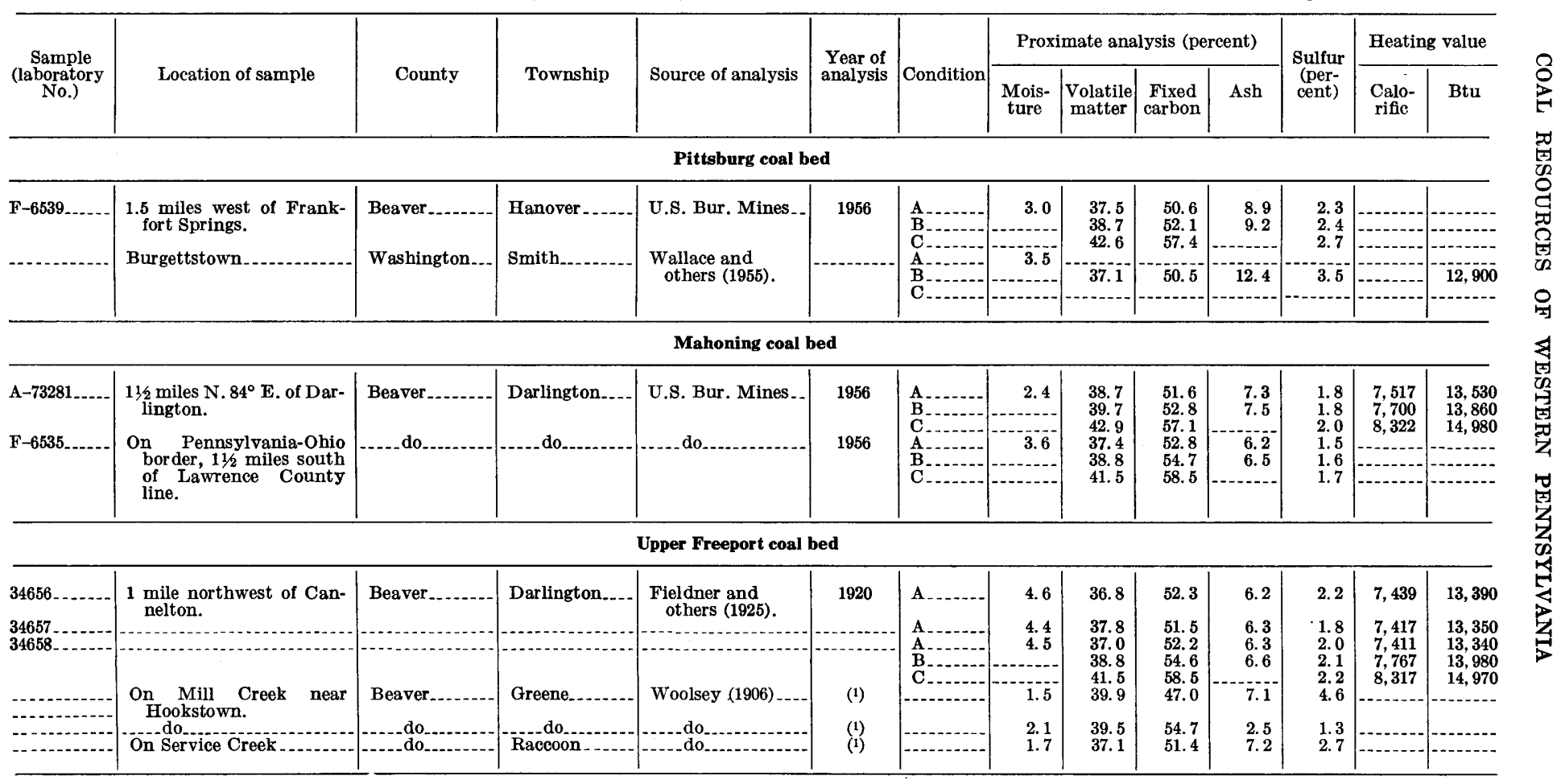


Lower Freeport coal bed

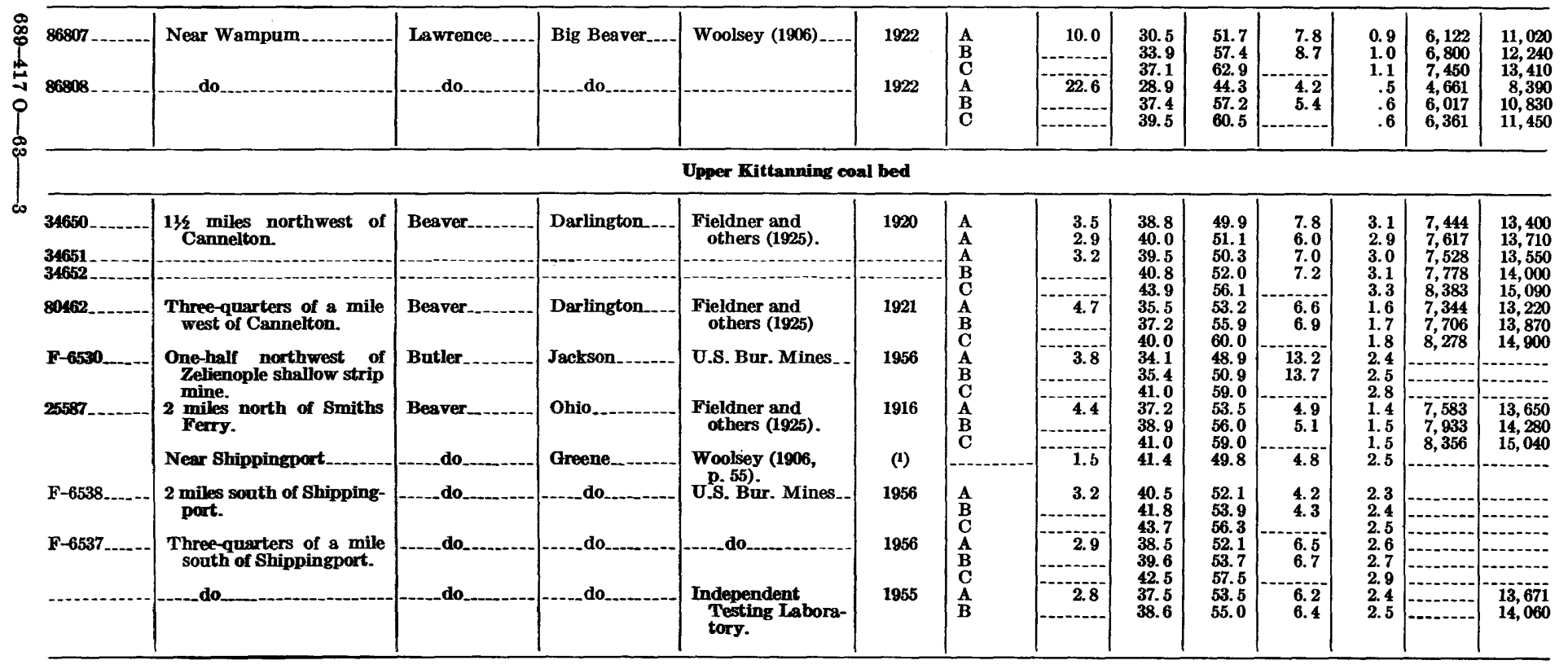

See footnotes at end of table. 
TABLE 5.-Analyses of coal samples from Beaver County, Pa., and adjaccnt areas-Continued

[Condition of sample: A, as received; B, moisture-free; C, moisture- and ash-free. Calorific heating value computed from Btu value]

\begin{tabular}{|c|c|c|c|c|c|c|c|c|c|c|c|c|c|}
\hline \multirow{2}{*}{$\begin{array}{c}\text { Sample } \\
\text { (laboratory } \\
\text { No.) }\end{array}$} & \multirow[b]{2}{*}{ Location of sample } & \multirow[b]{2}{*}{ County } & \multirow[b]{2}{*}{ Township } & \multirow[b]{2}{*}{ Source of analysis } & \multirow{2}{*}{$\begin{array}{l}\text { Year of } \\
\text { analysis }\end{array}$} & \multirow[b]{2}{*}{ Condition } & \multicolumn{4}{|c|}{ Proximate analysis (percent) } & \multirow{2}{*}{$\begin{array}{c}\text { Sulfur } \\
\text { (per- } \\
\text { cent) }\end{array}$} & \multicolumn{2}{|c|}{ Heating value } \\
\hline & & & & & & & $\begin{array}{l}\text { Mois- } \\
\text { ture }\end{array}$ & $\begin{array}{l}\text { Volatile } \\
\text { matter }\end{array}$ & $\begin{array}{l}\text { Fixed } \\
\text { carbon }\end{array}$ & Ash & & $\begin{array}{l}\text { Calo- } \\
\text { rific }\end{array}$ & Btu \\
\hline
\end{tabular}

Middle Kittanning coal bed

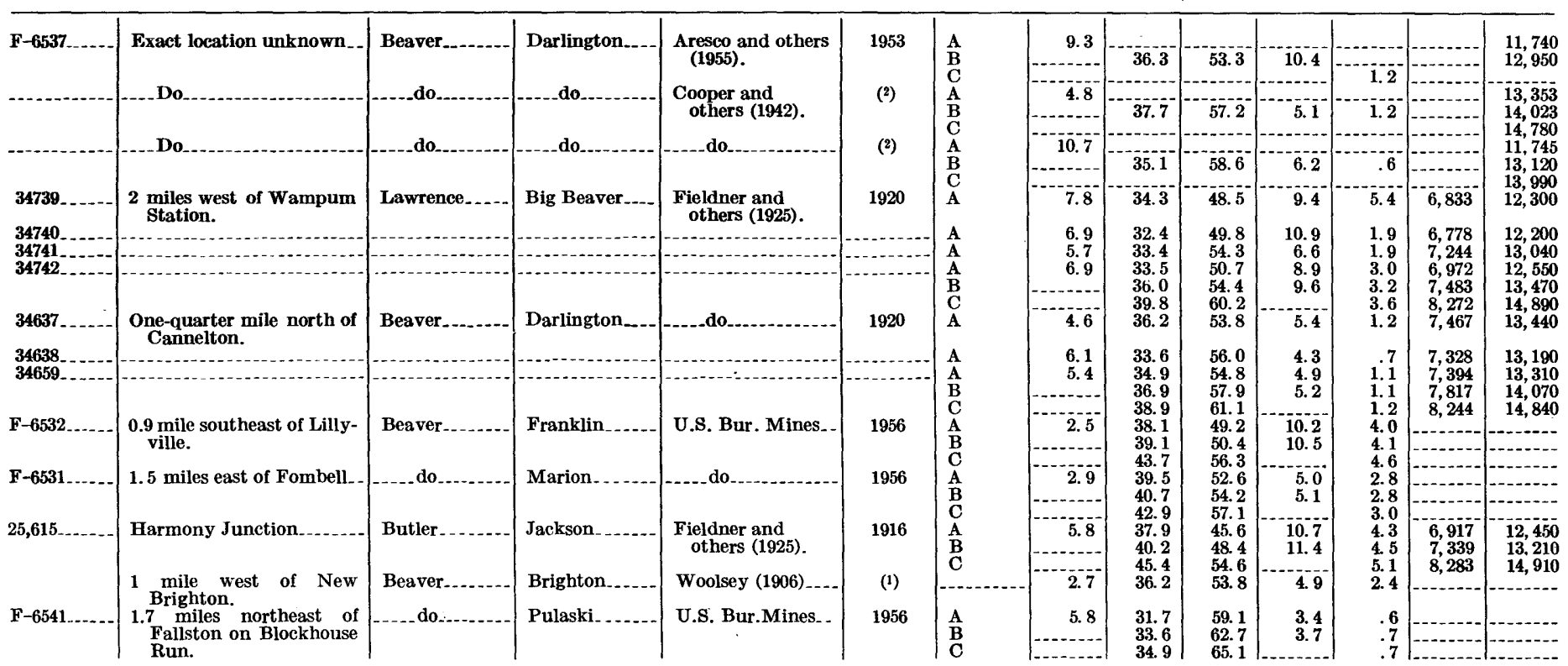


F-6536 \begin{tabular}{c|c}
0.3 mile east of railroad & \\
tracks on Crows Run. & \\
Georgetown &
\end{tabular}
New Sewickley.

Greene. - do-..-.--

$\mid$\begin{tabular}{l} 
Woolsey $(1906)$ \\
\hdashline$d 0$
\end{tabular}

1956

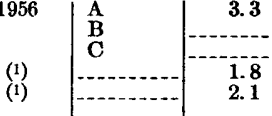

Lower Kittanning coal bed

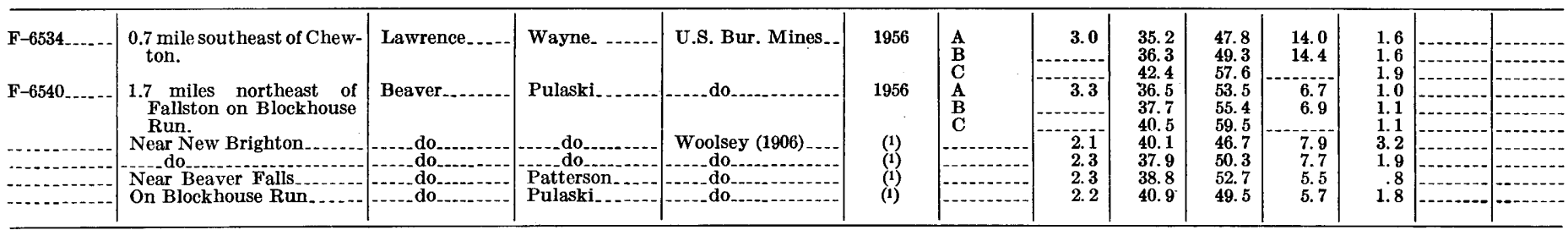

Clarion(?) coal bed

\begin{tabular}{|c|c|c|c|c|c|c|c|c|c|c|c|c|c|}
\hline F-6533 & $\begin{array}{l}\text { 2.1 miles southeast from } \\
\text { Pittsburgh and exit at } \\
\text { Ellwood City }\end{array}$ & Beaver......... & Franklin....... & U.S.Bur. Mines..- & 1956 & B. & \begin{tabular}{r}
5.7 \\
\hdashline-1 \\
$-0-1$
\end{tabular} & $\begin{array}{r}30.7 \\
32.6 \\
.36 .1\end{array}$ & $\begin{array}{l}54.5 \\
57.7 \\
63.9\end{array}$ & $\begin{array}{r}9.1 \\
9.7 \\
\hdashline-\end{array}$ & $\begin{array}{r}0.8 \\
.8 \\
.9\end{array}$ & $\begin{array}{l}-- \\
-- \\
-\end{array}$ & . \\
\hline \multicolumn{14}{|c|}{ Lower Mercer coal bed } \\
\hline $34653 \ldots$ & \multirow{2}{*}{$\begin{array}{l}\text { Location unknown (prob- } \\
\text { ably mined at depth). }\end{array}$} & \multirow[t]{2}{*}{ Beaver.......... } & & \multirow{2}{*}{$\begin{array}{l}\text { Fieldner and } \\
\text { others (1925). }\end{array}$} & \multirow[t]{2}{*}{1920} & & 3.8 & \multirow{2}{*}{$\begin{array}{l}36.7 \\
\\
34.0 \\
35.2 \\
\mathbf{3 6 . 6} \\
\mathbf{4 3 . 0}\end{array}$} & \multirow{2}{*}{$\begin{array}{l}48.3 \\
44.8 \\
46.8 \\
48.5 \\
57.0\end{array}$} & \multirow{2}{*}{$\begin{array}{r}11.2 \\
17.8 \\
14.4 \\
14.9\end{array}$} & \multirow{2}{*}{$\begin{array}{l}3.8 \\
4.9 \\
4.2 \\
4.4 \\
5.2\end{array}$} & \multirow{2}{*}{$\begin{array}{l}7,033 \\
\\
6,439 \\
6,739 \\
6,989 \\
8,217\end{array}$} & \multirow{2}{*}{$\begin{array}{l}12,660 \\
11,590 \\
12,130 \\
12,580 \\
14,790\end{array}$} \\
\hline $\begin{array}{l}34654 \\
34655\end{array}$ & & & & & & $\begin{array}{l}\mathbf{A} \\
\mathbf{A} \\
\mathbf{B}\end{array}$ & \begin{tabular}{|r|}
3.4 \\
3.6 \\
\hdashline-9 \\
-9
\end{tabular} & & & & & & \\
\hline
\end{tabular}

1 Before 1906

2 Before 1942. 


\section{COAL PRODUCTION}

Reported coal production in Beaver County during the period from 1881 to 1955 is 15 million tons (Maize and Struble, 1955). Production data are not available for each bed, but more coal seems to have been mined from the Upper Freeport bed than from any other bed. Combined production from the Upper Kittanning and Pittsburgh coal beds, both of which are largely depleted, is reported to be 1.41 million tons. As previously mentioned, production, when compared to original estimated reserves, is small.

Underground mining has accounted for most of the coal produced in Beaver County to the present time. Strip-mine production, however, has increased considerably in recent years.

\section{REFERENCES CITED}

American Society for Testing Materials, 1939, Standard specifications for classification of coals by rank: Philadelphia, Pa., 1939 Book of ASTM Standards (ASTM designation: D 388-38), pt. 3, p. 1-16.

Aresco, S. J., Haller, C. P., and Abernethy, R. F., 1955, Analyses of tipple and delivered samples of coal (collected during the fiscal year 1953): U.S. Bur. Mines Rept. Inv. 5085, 65 p.

Averitt, Paul, Berryhill, L. R., and Taylor, D. A., 1953, Coal resources of the United States (a progress report, October 1, 1953 : U.S. Geol. Survey Circ. 293, 49 p. [1954].

Chance, H. M., 1879, The northern townships of Butler County ; a special survey along the Beaver and Shenango Rivers in Beaver, Lawrence, and Mercer Counties : Pennsylvania Geol. Survey (2d), v. V, 248 p.

Cooper, H. M., Snyder, N. H., and Swingle, R. J., 1942, Analyses of Pennsylvania bituminous coals from July 1, 1937, to June 30, 1941 : U.S. Bur. Mines Tech. Paper 645, $19 \mathrm{p}$.

DeWolf, F. W., 1929, Topographic and geologic atlas of Pennsylvania no. 5, New Castle quadrangle; geology and mineral resources: Pennsylvania Geol. Survey, 4th ser., $238 \mathrm{p}$.

Fieldner, A. C., Cooper, H. M., and Osgood, F. G., 1925, Analyses of mine samples [of Pennsylvania coals] : Pennsylvania Geol. Survey, 4th ser., Bull. M 6, pt. 4, p. 13-256.

Graeber, C. K., and Foose, R. M., 1942, Geology and mineral resources [of the Brookville quadrangle]: Pennsylvania Geol. Survey, 4th ser., Topog. and Geol. Atlas of Pennsylvania, no. 54, 136 p.

Lesley, J. P., 1856, Manual of coal and its topography; Philadelphia, J. P. Lippincott and Co., $224 \mathrm{p}$.

- 1876, The Boyd's Hill gas well at Pittsburgh [Pennsylvania] : Pennsylvania Geol. Survey (2d), v. L, p. 217-237.

Maize, C. H., and Struble, G. S., compilers, 1955, History of Pennsylvania bituminous coal : Pennsylvania Dept. Mines, 65 p.

Munn, M. J., 1911, Description of the Sewickley quadrangle, Pennsylvania : U.S. Geol. Survey Geol. Atlas, Folio 176, 16 p.

Newberry, J. S., 1874, The Carboniferous system : Ohio Geol. Survey Rept. 2, pt. 1, p. 81-180. 
Platt, Franklin, 1875, Report of progress in the Clearfield and Jefferson district of the bituminous coal fields of western Pennsylvania: Pennsylvania Geol. Survey (2d), v. H, $296 \mathrm{p}$.

Reese, J. F., and Sisler, J. D., 1928, Bituminous coal fields of Pennsylvania; introductory volume, pt. 3, Coal resources: Pennsylvania Geol. Survey, 4th ser., Bull. M 6, pt. 3, 153 p.

Richardson, G. B., 1936, Geology and mineral resources of the Butler and Zelienople quadrangles, Pennsylvania : U.S. Geol. Survey Bull. 873, 93 p.

Rogers, H. D., 1840, Fourth annual report on the geological exploration of the State of Pennsylvania : Harrisburg, Pa., $215 \mathrm{p}$.

— 1858, the geology of Pennsylvania, A government survey : Philadelphia, J. D. Lippincott and Co., v. 1, 586 p. ; v. 2, 1046 p.

Stevenson, J. J., 1873, Notes on the geology of West Virginia: Am. Philos. Soc. Trans., new ser., v. 15, p. 15-32.

- 1876, Report of progress in the Greene and Washington districts of the bituminous coal fields of western Pennsylvania : Pennsylvania Geol. Survey (2d), v. K, $419 \mathrm{p}$.

Stout, Wilbur, and Lamborn, R. E., 1924, Geology of Columbiana County : Ohio Geol. Survey, 4th ser., Bull. 28, $408 \mathrm{p}$.

Van Tuyl, D. W. and Klein, N. H., 1951, Ground-water resources of Beaver County, Pennsylvania : Pennsylvania Geol. Survey, 4th ser., Bull. W 9, 84 p.

Wallace, J. J., Dowd, J. J., Provost, J. M., Abernethy, R. F., and Reynolds, D. A., 1955, Estimate of known recoverable reserves of coking coal in Washington County, Pennsylvania : U.S. Bur. Mines Rept. Inv. 5109, 23 p.

Wanless, H. R., 1939, Pennsylvanian correlations in the eastern Interior and Appalachian coal fields: Geol. Soc. America Spec. Paper 17, 130 p.

White, I. C., 1878, Report of progress in the Beaver River district of the bituminous coal fields of western Pennsylvania : Pennsylvania Geol. Survey (2d), v. Q, $337 \mathrm{p}$.

- 1879, The geology of Lawrence County; to which is appended a special report on the correlation of the coal measures in western Pennsylvania and eastern Ohio: Pennsylvania Geol. Survey (2d), v. QQ, 336 p.

1891. Stratigraphy of the bituminous coal field of Pennsylvania, Ohio, and West Virginia : U.S. Geol. Survey Bull. 65, $212 \mathrm{p}$.

Woolsey, L. H., 1906, Economic geology of the Beaver quadrangle, Pennsylvania [southern Beaver and northwestern Allegheny Counties] : U.S. Geol. Survey Bull. 286, 132 p. 



$$
\text { * }
$$


